\title{
Lexical specification of tone in North Germanic
}

\section{Aditi Lahiri, Allison Wetterlin \& Elisabet Jönsson-Steiner}

Accent 1 is very much accepted in the literature as the default tonal marker in Scandinavian languages. Consequently, stems and affixes are almost always specified for accent 2. Only rarely in some analyses is accent 1 specified for affixes, but never for stems. We believe that under these conditions, the resulting morphology/phonology interaction is rather complex, having to include special rules of accent marking, floating tones, deaccenting together with inexplicable exceptions. In our analysis of the tonal systems of Swedish and Norwegian, accent 1 is the lexically specified accent and accent 2 is postlexically assigned. Words and affixes may be lexically specified for accent 1 , which inevitably dominates. Consequently, if a morphologically complex word includes a lexically specified affix or stem, the entire word will bear accent 1 , giving us patterns of alternations like beskriva $a_{1}$, skriva $_{2}$. This analysis enables us to account for all the facts almost exceptionlessly, with no special tonal rules, constraints or templates.

Keywords accent $1 \& 2$, affixes, lexical accent, Norwegian, Swedish, tonal accent Aditi Lahiri, Allison Wetterlin \& Elisabet Jönsson-Steiner: University of Konstanz, Fachbereich Sprachwissenschaft,D-186 Konstanz 78457,Germany.E-mail:aditi.lahiri@uni-konstanz.de, allison.wetterlin@uni-konstanz.de,elisabet.joensson-steiner@uni-konstanz.de

\section{INTRODUCTION}

The general properties of the tonal opposition in North Germanic as accepted in the literature are given in (1) (based on Bruce 1977; Withgott \& Halvorsen 1984; Riad 1998a, b; Lahiri, Riad \& Jacobs 1999; Kristoffersen 2000; and references therein).

(1) Synopsis of the tonal opposition

NORTH GERMANIC (Central Swedish and Standard East Norwegian)

1. Tonal contrast is found in polysyllabic words

2. Accent 2 is lexically marked

3. Grammatical morphemes may come with accents (e.g. Swedish and Norwegian INFINITIVES are accent-2-inducing, cf. Withgott \& Halvorsen 1984, 1988; Riad 1998a; Kristoffersen 2000) 
A disyllabic domain is indispensable for the realisation of accent contrast in the Scandinavian languages, as we see in (2). ${ }^{1}$ Consequently, monosyllabic words in Swedish and Norwegian invariably bear accent 1 .

\section{(2) Accent contrast domains}

Swedish and Norwegian:

$$
\begin{aligned}
& \text { 'tank }_{1}, \text { 'tanken }_{1} \quad \text { 'tank'/'tank' }{ }_{\text {DEF }} \\
& \text { 'tanke } 2, \text { 'tanken } 2
\end{aligned}
$$

As for tonal contours, although specific analyses differ, the general assumption is that accent 1 and 2 have opposing specifications, and accent 2 is mentioned as the marked member (Haugen \& Joos 1952; Haugen 1967/1983; Elert 1972; Bruce 1977; Endresen 1977; Hoel 1981; Lorentz 1984; Withgott \& Halvorsen 1984, 1988; d'Alquen \& Brown 1992; Kristoffersen 1992, 1993, 2000; Gussenhoven \& Bruce 1999; Riad 2003a, b). Researchers are divided on the issue whether tone is privative or equipollent. Those who view accent as privative, claim that accent 2 is lexical and accent 1 is the absence of lexical tone (Rischel 1963/1983; Haugen 1967/1983; Elert 1970, 1972; Linell 1972; Kristoffersen 1992, 1993, 2000; Riad 2003a, b; and others). Even amongst proponents of privative accent, there are differences in the details of their specifications. Kristoffersen (2000) and Riad (2003a, b) assign lexical accent (accent 2), or a floating $H$, to stems and morphemes. As we will see later, Kristoffersen (2000:262f.) includes suffixes that are subcategorised for 'deaccenting' (thereby making reference to absence of lexical tone as a category), while Riad (1998a:86, fn. 29) uses 'deaccenting' as a process.

The alternative approach is to view accent as equipollent (Haugen \& Joos 1952, Linell 1972, Bruce 1977, Endresen 1977, Hoel 1981, Lorentz 1984, Gussenhoven \& Bruce 1999), where the difference between the two accents lies in the tonal alignment: accent 1 is $\mathrm{HL}^{*}$ while accent 2 is $\mathrm{H}^{*} \mathrm{~L}$. Morphemes are usually accent-2-inducing or neutral (Bruce \& Hermans 1999).

In Withgott \& Halvorsen's analysis for Standard East Norwegian, there is a binary opposition in tone and a three-way distinction in affixes. The authors too implicitly presume that accent 2 is the more prominent accent and that stems can bear only accent 2 or an $\mathrm{H}$ tone. Affixes, though, may be lexically specified for both accent 1 (L) and accent $2(\mathrm{H})$ : accent-2-inducing, accent-1-inducing, or neutral.

There are crucial differences in the phonetic realisation of word accents across dialects, though this is not the focus of this paper. What is significant, is that all phonological analyses agree that there is contrast in tonal accent both in Swedish and Norwegian, and that the default tone is accent 1 . Accent 2 is accepted as 
phonologically dominant, and this is precisely what we take issue with in this paper.

In what follows, we will argue that in both Swedish and Norwegian, the lexically specified tone is, on the contrary, always accent 1 . This implies that grammatical morphemes can only be specified for accent 1 , and never accent 2 . If no lexical accent is available, then postlexical accent assignment assures accent 2 for polysyllabic words. Monosyllabic words, due to structural requirements, can only have accent 1. Our claim is that lexically specified accent 1 always dominates. Further, Standard East Norwegian differs from Central Swedish (but perhaps not from other Southern Swedish dialects) in that monosyllabic words can contrast lexically as being specified for accent 1 or being unspecified. This specification plays a major role in compound accent assignment.

We begin, in section 2, with an overview of published accounts of accent assignment with morphologically complex words and, in section 3, enumerate our main concerns with anomalies involving accent 1 that previous analyses repaired largely by employing exceptional deaccenting rules. Our initial analysis of Central Swedish (section 3.1) is then extended to Standard East Norwegian (section 3.2). This is followed by a brief analysis of Norwegian compounds (section 4) showing how not only affixes and polysyllabic words, but also lexical words may be exceptionally specified for accent 1 . Finally, in section 5 , we provide a representation of Scandinavian accents according to our analysis together with a discussion of what comprises lexical accent.

\section{MORPHOPHONOLOGICAL ISSUES IN ACCENT ASSIGNMENT IN SWEDISH AND NORWEGIAN}

Although North Germanic languages rarely use only tone to contrast grammatical categories, ${ }^{2}$ both Swedish and Norwegian are claimed to have grammatical morphemes with specified tones which dock onto the stem during affixation. Riad (1998a), Bruce \& Hermans (1999) and Kristoffersen (2000) all maintain that many affixes are specified for accent 2 which may spread to the stressed syllable of the stem giving the entire word accent 2. According to Riad (1998a:72), for example, the infinitive suffix $\{-a\}$ bears a lexical $\mathrm{H}$ tone, or accent 2 , which aligns to the stressed syllable of the verb. In Riad's analysis, morphemes can only be marked for accent 2, never accent 1 . Bruce \& Hermans (1999) also follow a similar track assuming that there is a distinction between affixes that change the accent of a word (accent2-inducing affixes) and those which do not affect accent (accent neutral affixes). For Norwegian, Withgott \& Halvorsen (1984) as well as Kristoffersen (2000) also assume 
that the infinitive suffix induces accent 2. Examples of accent contrasts in Swedish and Norwegian verbs are given in (3).

(3) Accent contrasts in verbs

\begin{tabular}{|c|c|c|c|}
\hline SWEDISH & IMPERATIVE $\{\varnothing\}$ & INFINITIVE $\{-a\}$ & GLOSS \\
\hline \multirow[t]{3}{*}{ Monosyllabic Roots } & Accent 1 & Accent 2 & \\
\hline & 'läs ${ }_{1}$ & 'läsa 2 & 'read' \\
\hline & 'bygg 1 & 'bygga $_{2}$ & 'build' \\
\hline \multirow[t]{3}{*}{ Disyllabic Roots } & Accent 2 & Accent 2 & \\
\hline & spela $_{2}$ & 'spela $_{2}$ & 'play' \\
\hline & 'tala 2 & 'tala 2 & 'talk' \\
\hline NORWEGIAN & IMPERATIVE $\{\varnothing\}$ & INFINITIVE $\{-e\}$ & GLOSS \\
\hline \multirow[t]{3}{*}{ Monosyllabic Roots } & Accent 1 & Accent 2 & \\
\hline & 'bygg 1 & 'bygge $_{2}$ & 'build' \\
\hline & 'tal 1 & 'tale 2 & 'talk' \\
\hline
\end{tabular}

Since monosyllabic words can only bear accent 1 , the imperatives of the monosyllabic roots are accent 1 for both Swedish and Norwegian. Swedish, however, also has disyllabic roots, all ending in [a], as we can see from the imperatives with accent 2. The infinitive form here is homophonous with the imperative since a sequence of two identical vowels is not tolerated.

With respect to general accent assignment in the published literature, we could summarise as follows. Despite some variation, Withgott \& Halvorsen and Kristoffersen come to very similar general conclusions. Withgott \& Halvorsen assume Norwegian affixes can induce accent 1 , accent 2 or be neutral. ${ }^{3}$ Stems, on the other hand, may only bear accent 2 . They distinguish between dominant and non-dominant affixes, and only affixes bearing accent 2 may be non-dominant. In Kristoffersen's analysis, affixes can have floating H, be neutral, or accent deleting. Default accent for both analyses is accent 1. For Swedish, Riad asserts that affixes may induce accent 2 and stems may also come with accent 2, i.e. affixes and stems can have a floating H. Again, unless specified otherwise, default accent is accent 1. In addition, there are some accent-deleting rules where accent 1 dominates; this is quite similar to Kristoffersen's analysis. Before discussing individual examples in detail, the complexity of accent assignment in Swedish is illustrated in (4) with a small excerpt of a flow chart from Bruce (1977). 
(4) Swedish accent assignment (partial flow chart adapted from Bruce 1977:18)

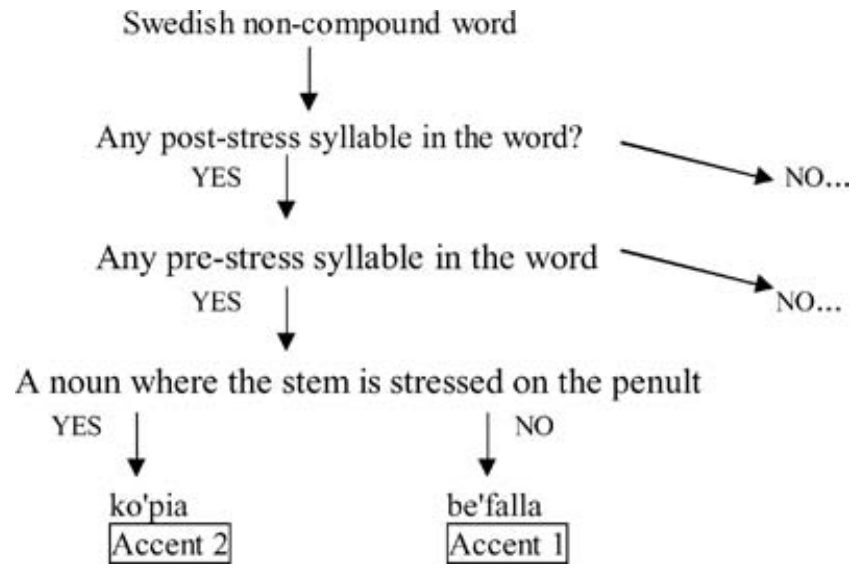

Bruce's accent assignment diagram shows the intricate patterns of interaction between morphology, stress and accent in Swedish. The diagram, however, fails to distinguish the regularities from the systematic oddities. For instance, the word befalla gets accent 1 in the diagram because (i) there is a pre-stress syllable in the word, (ii) there is a post-stressed syllable in the word, and (iii) it is not a noun with penultimate stress. The fact is, however, that it is not only the prosodic structure and morphological category of this type of word that determines the accent, but more generally all verbs with unstressed prefix be-, för-/for-, ent- (in Swedish and Norwegian) bear accent 1 exceptionlessly. ${ }^{4}$ In fact, the tree has exceptions: A noun that is stressed on the penultimate and has a pre-stressed and post-stressed syllable will, nevertheless, receive accent 1 if it contains the unstressed prefix för-as in för'skrivning 1 'perscription', cf. skrivning 2 'writing'. The infinitive suffix - $a$ normally always goes hand in hand with accent 2 (cf. (3) above), but is overridden here, as in (5), when $b e$ - is added.

(5) Exceptions to accent 2 of Swedish INF $\{-\mathrm{a}\}$ and Norwegian INF $\{-\mathrm{e}\}$

a. Swedish verb 'stämma 'to tune'

\begin{tabular}{lll}
\hline IMPERATIVE & INFINITIVE & GLOSS \\
\hline 'stäm 1 & 'stämma & 'tune' \\
\hline be-'stäm $_{1}$ & be-'stämma & 'decide' \\
\hline 'tala 2 & 'tala & 'speak' \\
\hline be-'tala $_{1}$ & be-'tala & 'pay' \\
\hline
\end{tabular}


b. Norwegian verb 'stemme 'to tune'

\begin{tabular}{lll}
\hline IMPERATIVE & INFINITIVE & GLOSS \\
\hline 'stem $_{1}$ & 'stemme & 'tune' \\
\hline be-'stem $_{1}$ & be-'stemme $_{1}$ & 'decide' \\
\hline
\end{tabular}

Indeed, if we look at such exceptions systematically, in both Norwegian and Swedish, the culprit is a particular set of affixes, be-, för-/for-, ent-, causing the exceptions that, interestingly enough, ALL involve accent 1 and not accent 2.5 Recall, that for both Swedish and Norwegian, it is generally accepted that accent 1 is never marked on stems. It is accent 2 which should be marked on affixes and stems.

Furthermore, the above alternations are dealt with in different ways. Withgott $\&$ Halvorsen (1984:14) analyse such affixes in Norwegian as bearing dominant accent 1 that overrides all other tonal specification. Kristoffersen (2000:262) deals with these affixes using a morphological constraint on tonal feet built by morphological rules: they must be at the left edge of a word for the floating $\mathrm{H}$ to associate to the stressed syllable, ${ }^{6}$ and Riad (1998a:86, fn. 29) employs deaccenting rules.

(6) Analysis of Swedish be'stämma and Norwegian be'stemme

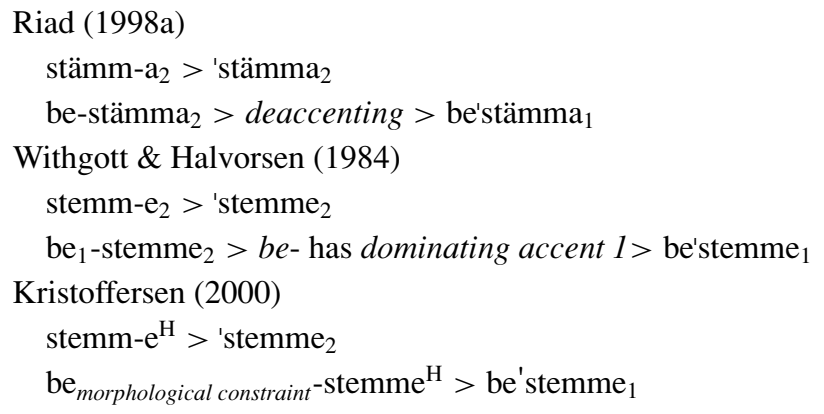

Riad's deaccenting rule, Kristoffersen's morphological constraint and Withgott \& Halvorsen's accent 1 dominant suffixes are devised specifically for such alternations. Otherwise accent 2 suffixes do most of the work. Another curious fact is that Withgott \& Halvorsen's accent-1-inducing suffixes override everything else. Accent 2 suffixes may be dominant or weak, i.e. can be overridden. Deaccenting essentially means accent 1 wins. Thus, in spite of the fact that accent 1 is considered to be the default by all these authors, the marked exceptions seem to always involve accent 1 , and vice versa if accent 1 is involved, it always dominates. 
Is it possible to turn the tables and provide an alternative analysis assuming accent 1 is lexically marked and accent 2 is assigned by postlexical rules? Could such an analysis be more transparent? We will attempt to provide such an analysis for both Central Swedish and Standard East Norwegian. We begin with the infinitive, claiming that this suffix does not carry accent 2. Rather, the lexical organisation of both languages is such that only accent 1 is specified and accent 2 is assigned by rule. We will provide further evidence from compounds in both languages and end with some diachronic speculations.

\section{LEXICAL MARKING OF ACCENT 1 IN SWEDISH AND NORWEGIAN}

On the basis of preceding analyses and our own alternative assertion, we could entertain the following competing hypotheses for lexical accent marking:

(7) Competing hypotheses for accent marking in Swedish and Norwegian

HYPOTHESIS A: Affixes can be marked for accent 1 and 2 .

$\begin{array}{ll}\text { INFINITIVE }\left\{-a_{2}\right\} \text { (Swedish) } /\left\{-e_{2}\right\} \text { (Norwegian) } & \text { is marked for accent } 2 \\ \text { PREFIX } \quad\{b e-1\} \text { (Swedish/Norwegian) } & \begin{array}{l}\text { is marked for accent } 1, \\ \text { deaccenting prefix }\end{array} \\ \text { Swedish }\left\{b e-{ }_{1}\right\}\{\text { stämm }\}\left\{-a_{2}\right\} & \left.\begin{array}{l}\text { Accent } 1 \text { of }\{b e-1\} \\ \text { associates to the stressed } \\ \text { Norwegian }\left\{b e-{ }_{1}\right\}\{\text { stemm }\}\left\{-e_{2}\right\}\end{array}\right\} \rightarrow \quad \begin{array}{l}\text { syllable; accent } 2 \text { of the } \\ \text { infinitive }\left\{-a_{2}\right\} /\left\{-e_{2}\right\} \text { is } \\ \text { overridden/deaccented }\end{array}\end{array}$

HYPOTHESIS B: Affixes can only be marked for accent 1 ; accent 2 is assigned by postlexical rules.

$\begin{array}{ll}\text { INFINITIVE }\{-a\} \text { (Swedish), }\{-e\} \text { (Norwegian) } & \text { no accent specified } \\ \text { PREFIX }\{b e-1\} \text { (Swedish/Norwegian) } & \text { specified for accent } 1 \\ \text { Swedish }\{b e-1\}\{\text { stämm }\}\{a\} & \begin{array}{l}\text { Accent } 1 \text { of }\{b e-1\} \\ \text { associates to the stressed } \\ \text { syllable }\end{array}\end{array}$

We believe that hypothesis B is preferable since there is only one lexically specified accent, accent 1 . Moreover, we will show that non-affixed as well as affixed forms, which surface with or without accent 2 , are easily accounted for 
under hypothesis B. Our claim is that all that is necessary is a postlexical accenting rule assigning accent 2 to all polysyllabic words without lexical accent.

\section{(8) Postlexical accent assignment}

Every polysyllabic word, consisting of at least one disyllabic trochee, if not lexically specified for accent 1 is assigned accent 2; else, accent 1 .

Accent 1 can be specified on prefixes, suffixes or stems. Its presence will ALWAYS block the postlexical rule. The elsewhere condition covers all polysyllabic words with final stress and all monosyllabic words which are not lexically specified for accent 1. In what follows, we elaborate on our hypothesis and show how all the data can be successfully handled. Indeed, all peculiarities, all exceptions, under this account, are due to idiosyncratic marking of lexical accent 1 .

\subsection{Synchronic analysis for Central Swedish}

Our analysis for Central Swedish states that lexically there is only accent 1 . No morpheme or word bears accent 2 lexically. In (9), we list some words and affixes that are lexically specified for carrying accent 1 and (10) gives the accent assignment rules for Central Swedish.

\section{(9) Lexical accent marking in Central Swedish}

All morphemes can bear accent 1 .

Words with lexical accent: 'termos 1 'thermos', 'fänrik $k_{1}$ 'ensign', 'taxi $i_{1}$, etc. names of places: 'Märsta $a_{1}, A^{\prime} m e r i k a_{1}$, etc. days of the week: $\quad$ 'lördag ${ }_{1}$ 'Saturday', 'maindag 1 'Monday', etc.

Prefixes with accent 1: $\quad$ be-1, för $_{-1}$, ent $_{-1}$

Suffixes with accent 1: -'era $1,-' i s k_{1}$, etc.

\section{(10) Accent assignment in Central Swedish}

a. Accent 1 is lexically specified on morphemes.

b. Postlexical accent assignment (if not lexically specified)

$\left\{\ldots \sigma^{\prime} \sigma \ldots\right\}_{\omega} \rightarrow$ accent 2 ;

$\left\{\ldots \sigma^{\prime}\right\}_{\omega} \rightarrow$ accent 1

Lexically specified accent is never overridden by the postlexical accent assignment. Thus, according to our analysis, no word or morpheme bears accent 2 lexically. Accent 2 is a result of the postlexical accent assignment rule. When a morpheme carries lexical accent 1 this accent will dock onto the nearest stressed 
syllable. Note that after morpheme concatenation, if there is any morpheme bearing accent 1 , it will prevail. In what follows, we discuss accent assignment in connection with verbs and affixation (section 3.1.1) and then turn to nouns, their endings and accent assignment in section 3.1.2.

\subsubsection{Verbs and their affixes}

The infinitive suffix in Swedish is $\{-a\}$, as we have seen before. In the present tense, there is a single suffix $\{-r\}$ that is not distinguished by person or number. In the following, we will give our analysis of the infinitive and present tense with and without derivational suffixes.

\subsubsection{Swedish infinitive}

In (11) we give examples of stress and accent assignment for the Swedish infinitive.

(11) Swedish infinitive and $\left\{\mathrm{be}_{-1}\right\}$ prefix

$\begin{array}{llll}\text { LEXICAL } & & \text { ACCENT } & \\ \text { REPRESENTATION } & \text { STRESS } & \text { ASSIGNMENT } & \text { GLOSS } \\ / \mathrm{be}_{1} / / \mathrm{tala} / \mathrm{a} / & \text { be }_{1}{ }^{\text {tala }} & \text { be'tala }_{1} & \text { 'pay' } \\ / \text { tala//a/ } & \text { 'tala } & \text { 'tala }_{2} & \text { 'speak' } \\ / \mathrm{be}_{1} / / \mathrm{stämm} / / \mathrm{a} / & \text { be }_{1} \text { 'stämma } & \text { be'stämma }_{1} & \text { 'decide' } \\ / \text { stämm//a/ } & \text { 'stämma } & \text { 'stämma } & \text { 'tune' }\end{array}$

Since the unstressed prefix $\left\{b e_{-1}\right\}$ bears accent 1 , this accent associates to the stressed syllable of the root tala, which is not lexically specified. However, without the prefix, the infinitive form, which is identical to the root, is postlexically assigned accent 2 since it consists of a disyllabic trochee. The monosyllabic root stämm also gets accent 2 after the infinitive suffix is added, making it disyllabic. It bears no lexical accent. However, the prefix $\left\{b e_{-1}\right\}$ adds its lexical accent 1 to stämma giving be'stämma accent 1.

\subsubsection{Swedish present tense}

The present tense suffix $\{-r\}$ in Swedish triggers epenthesis. Therefore, the final accent of the verb depends on the syllabicity of the root, not the suffix. As soon as an accent-1-specified prefix is added, the verb ONLY bears accent 1 regardless of the number of syllables. We illustrate this below in (12). 
(12) Present tense suffix $\{-\mathrm{r}\}$ in Central Swedish

LEXICAL

\begin{tabular}{|c|c|c|c|c|}
\hline REPRESENTATION & $\operatorname{IMPER}\{\varnothing\}$ & $\operatorname{INF}\{-a\}$ & PRES $\{-r\}$ & GLOSS \\
\hline /stämm/ & 'stäm 1 & 'stämma 2 & 'stämmer ${ }_{1}$ EPEN & 'tune' \\
\hline /bygg/ & 'bygg & 'bygga 2 & 'bygger ${ }_{1}$ EPEN & 'build' \\
\hline /läs/ & 'läs 1 & 'läsa 2 & 'läser ${ }_{1}$ EPEN & 'read' \\
\hline /sluta/ & 'sluta 2 & 'sluta 2 & 'slutar 2 & 'stop' \\
\hline /tala/ & 'tala 2 & 'tala 2 & 'talar 2 & 'speak' \\
\hline /skapa/ & 'skapa 2 & 'skapa 2 & 'skapar 2 & 'create' \\
\hline$/ \mathrm{be}_{1} / / \mathrm{stämm} /$ & be'stäm 1 & be'stämma 1 & be'stämmer ${ }_{1}$ EPEN & 'decide' \\
\hline$/ \mathrm{be}_{1} / /$ tala/ & be'tala $_{1}$ & be'tala $_{1}$ & be'talar $_{1}$ & 'pay' \\
\hline
\end{tabular}

Note that the prefixed and non-prefixed PRES forms of tala take the suffix $\{-r\}$, and 'talar bears accent 2. This is because the final vowel is not epenthetic but an inherent part of the root. On the other hand, be'talar is accent 1, independent of the number of the syllables in the root. The underlying accent 1 of the prefix $\{b e-1\}$ overrides everything else. For monosyllabic roots like stämm, both the present tense forms be'stämmer ${ }_{1}$ and 'stämmer 1 bear accent 1 . The former is due to the lexically specified prefix and the latter is because this form is not really disyllabic, the final vowel is epenthetic.

\subsubsection{Nouns and their endings}

In this section, we will discuss the indefinite plural suffix, the definite singular and plural clitics, and derivational affixes providing further evidence that lexically specified accent 1 dominates.

\subsubsection{Swedish indefinite singular and plural: common gender}

The Swedish indefinite plural has four surface forms [-r], [-ar], [-or], [-er] for the common gender. Examples of some plural forms are given in (13).

(13) Swedish indefinite plural forms: common gender

\begin{tabular}{|c|c|c|c|}
\hline & SINGULAR & PluRAL & GLOSS \\
\hline a. & 'lag 1 & 'lagar, & 'law’ \\
\hline b. & 'dikt $_{1}$ & 'dikter $_{2}$ & 'poem' \\
\hline c. & 'månad 2 & 'månader 2 & 'month' \\
\hline d. & 'flicka2 & 'flickor 2 & 'girl' \\
\hline e. & 'opera $_{1}$ & 'operor 1 & 'opera' \\
\hline
\end{tabular}




\begin{tabular}{|c|c|c|c|}
\hline f. & studie $_{1}$ & 'studier 1 & 'study' \\
\hline g. & 'fänrik 1 & 'fänrikar 1 & 'ensign' \\
\hline h. & 'handling 2 & 'handlingar. & 'act, action' \\
\hline i. & be'handling $_{1}$ & be'handlingar $_{1}$ & 'treatment' \\
\hline j. & 'åker 1 & 'åkrar 2 & 'field' \\
\hline $\mathrm{k}$. & 'regel $_{2}$ & 'reglar 2 & 'latch' \\
\hline 1. & 'regel $_{1}$ & 'regler 1 & 'rule' \\
\hline m. & stu'dent $_{1}$ & stu'denter $_{1}$ & 'student' \\
\hline n. & gene'rator $_{2}$ & genera'torer $_{1}$ & 'generator' \\
\hline o. & pro'fessor $_{2}$ & profes'sorer $_{1}$ & 'professor' \\
\hline
\end{tabular}

Within our analysis, the underlying form of the indefinite plural suffix has the overall pattern $\{-\mathrm{V} r\}$ and does not carry any accent. This means that there is no underlying [-r] suffix. What looks like an [-r] suffix is underlyingly /-er/. The quality of the vowel of the $\{-\mathrm{V} r\}$ suffix is probably determined by segmental and morphological factors. We offer some tentative suggestions concerning the predictability of the surface forms. The suffix [-ar] is the most frequent indefinite plural suffix. Both [-er] and [-ar] have to be subcategorised for specific morphemes; for instance, derivational suffixes $\{-$ or $\}\{$-nad $\},\{$-skap $\},\{-(n) \ddot{a} r\},\{$-het $\},\{-e l s e\},\{-i o n\}$ (cf. (13)) always take the [-er] plural while $\{-d o m\}$ and $\{-$-ing $\}$ take [-ar] (cf. (13)). Stems ending in $a$ lose this vowel before the plural suffix [-or] (cf. (13)).

As before, the accent 1 stems or affixes, like $\left\{b e_{-1}\right\}$ (cf. (13)) determine the ultimate plural accent. Below we repeat (13), showing the stress and accent assignment with the appropriate vowel quality of the plural suffix. We will discuss each type of example in turn.

(14) Lexical representations of stems plus $\{-\mathrm{Vr}\}$ indefinite plural suffix

\begin{tabular}{|c|c|c|c|c|}
\hline & \multicolumn{2}{|c|}{ LEXICAL REPRESENTATION } & SINGULAR & PlURAL \\
\hline a. & /lag/ & $/ \mathrm{Vr} /$ & 'lag & 'lagar > 'lagar2 \\
\hline b. & /dikt/ & $/ \mathrm{Vr} /$ & 'dikt & 'dikter $>$ 'dikter 2 \\
\hline c. & /månad/ & $/ \mathrm{Vr} /$ & 'månad $_{2}$ & 'månader > 'månader 2 \\
\hline $\mathrm{d}$. & /flicka/ & $/ \mathrm{Vr} /$ & 'flicka 2 & 'flickor > 'flickor 2 \\
\hline e. & /opera $_{1} /$ & $/ \mathrm{Vr} /$ & 'opera $_{1}$ & 'oper $_{1}$ or $>$ 'operor $_{1}$ \\
\hline f. & /studie 1 / & $/ \mathrm{Vr} /$ & studie $_{1}$ & studie $_{1}$ er $>$ 'studier 1 \\
\hline g. & /fänrik ${ }_{1} /$ & $/ \mathrm{Vr} /$ & 'fänrik ${ }_{1}$ & 'fänrik ${ }_{1}$ ar > 'fänrikar 1 \\
\hline h. & /hand//ling/ & $/ \mathrm{Vr} /$ & 'handling 2 & 'handlingar > 'handlingar 2 \\
\hline
\end{tabular}




\begin{tabular}{|c|c|c|c|c|}
\hline i. & /be $1 / /$ handling/ & $/ \mathrm{Vr} /$ & be $_{1}$ 'handling & be $_{1}{ }^{\prime}$ handlingar $>$ be'handlingar 1 \\
\hline j. & /åkr/ & /Vr/ & 'åker 1 & 'åkrar > åkrar 2 \\
\hline $\mathrm{k}$. & /regel/ & $/ \mathrm{Vr} /$ & 'regel $_{2}$ & 'regelar > 'reglar 2 \\
\hline 1. & $/ \mathrm{regl}_{1} /$ & $/ \mathrm{Vr} /$ & 'regel $_{1}$ & 'regl $_{1}$ er > regler $_{1}$ \\
\hline $\mathrm{m}$. & /student ${ }_{1} /$ & $/ \mathrm{Vr} /$ & stu'dent $_{1}$ & stu'dent $_{1}$ er $>$ stu'denter $_{1}$ \\
\hline n. & $/$ genera'tor $_{1} / \mathrm{PL}$ & /Vr/ & gene'rator $_{2}$ & genera'tor $_{1}$ er $>$ genera'torer $_{1}$ \\
\hline o. & $/$ profes'sor $_{1} / \mathrm{PL}$ & $/ \mathrm{Vr} /$ & pro'fessor $_{2}$ & profes'sor $_{1}$ er $>$ profes'sorer ${ }_{1}$ \\
\hline
\end{tabular}

Recall that the plural suffix carries no lexical tone. Thus, words not marked for lexical accent get accent 2 in the plural if a disyllabic trochee is available. In (14a, b), a monosyllabic word becomes disyllabic and surfaces with default accent 2 , as in 'lagar, 'dikter. In (14c, d), lexically unmarked disyllabic words with initial stress surface with default accent 2 in the plural, 'månader, 'flickor. In contrast, lexically specified disyllabic words with initial stress remain accent 1 in the plural, as in (14e-g), 'operor $_{1}$, 'studier 1 , 'fänrikar. In morphologically complex words 'handlingar 2 , be'handlingar $_{1}$, in $(14 \mathrm{~h}, \mathrm{i})$, once again morphemes that are lexically marked for accent 1 like $\left\{b e_{-1}\right\}$ (see (14i)) determine the accent of the plural, or the plural has default accent 2 since no lexical accent prevails (see (14h)).

As seen in (14j), certain disyllabic words ending in $r$ or $l$ ostensibly have two syllables in both the singular and the plural, yet the singular bears accent 1 whereas the plural, with the suffix $\{-a r\}$ bears accent 2: cf. 'aker ${ }_{1}$, 'åkrar 2 . There are, however, other accentual patterns as well. Below we compare monosyllabic and disyllabic stems ending in $r$ and $l$.

\section{Swedish monosyllabic and disyllabic stems ending in sonorants}

\begin{tabular}{|c|c|c|c|c|c|c|}
\hline & $\begin{array}{l}\text { LEXICAL } \\
\text { REPRESENTATION }\end{array}$ & STRESS & $\begin{array}{l}\text { POSTLEXICAL } \\
\text { ACCENT ASSIGN }\end{array}$ & SYNCOPE & EPENTHESIS & GLOSS \\
\hline $\mathrm{a}$ & /åkr/ & 'åkr & 'åkr & & 'åker 1 & 'field' \\
\hline b & /åkr/ /ar/ & 'åkrar & 'åkrar, & & & 'fields' \\
\hline $\mathrm{c}$ & /regel/ & 'regel & ${ }^{\prime}$ regel 2 & & & 'latch' \\
\hline d & /regel//ar/ & 'regelar & 'regelar $_{2}$ & 'reglar 2 & & 'latches' \\
\hline e & $/ \mathrm{regl}_{1} /$ & $\operatorname{regl}_{1}$ & & & 'regel $_{1}$ & 'rule' \\
\hline $\mathrm{f}$ & $/ \mathrm{regl}_{1} / / \mathrm{er} /$ & 'regler $_{1}$ & & & & 'rules' \\
\hline
\end{tabular}

We assume with others (Rischel 1963/1983:271, Riad (p.c.)) that words like åker are monosyllabic stems, which surface as disyllabic in the singular after epenthesis just like some present tense forms. However, unlike other analyses, the plural suffix does 
not bear accent 2 ; the word is assigned default accent 2 postlexically after the addition of a syllable. The singular of regel in (15) differs from $\stackrel{a}{a} k$ in that it is disyllabic in the singular and does not need an epenthetic vowel. Its plural is also disyllabic not trisyllabic, 'reglar since the final schwa of the stem is deleted. The accent of the singular and plural are both postlexical accent 2 .

In (15), we have chosen to mark the monosyllabic stems with lexical accent 1: $/ \mathrm{regl}_{1} /$. Consequently, the singular and the plural forms both maintain accent 1 . Another option would be to assume that the suffix for these words is not $\{-\mathrm{V} r\}$ but $\{-r\}$, as hypothesised by Riad (2003b:2), thereby allowing epenthesis in the plural and maintaining accent $1: r e g l+r>r e g l r_{1}>$ regler ${ }_{1} .{ }^{8}$ The same effect occurs in $(14 n, o)$. The singular form is stressed on the penult, pro'fessor 2 but the plural has accent 1 with the stress on the final syllable of the stem, profes'sor+er. Again, one could assume that the suffix is $\{-r\}$, and the stress is marked specially for the plural stem which obtains the same effect as regler with epenthesis: profes'sor $+r>$ profes'sorer $_{1}$.

We have chosen to mark the words in $(14 \mathrm{~m}, \mathrm{n}, \mathrm{o})$ for accent 1 , since the plural surfaces with [-er] and accent 1 . Had the stems been unmarked for tone, the addition of the plural morpheme (i.e. the addition of a syllable) would lead to default accent 2 , as in (14b), where the plural form dikter $_{2}$ adds a syllable to the monosyllabic stem and surfaces with default accent 2 , as we would predict.

Our decision to specify special monosyllabic stems and stems with final stress with accent 1 (assuming that the plural stem of words like profes'sor are finally stressed) is based on Norwegian. As we will argue in section 4, Norwegian has monosyllabic and polysyllabic stems specified for accent 1 that affect the accent of the compound. We would predict that these lexically specified stems would also show an effect on compounds in Swedish dialects that have tonal contrast in compounds (like the Malmö dialect). For Central Swedish, there is no other independent evidence as far as we are aware - and the choice between assuming an additional $\{-r\}$ plural suffix and assuming a lexical contrast between monosyllabic words rests on particular analyses. We keep this question open for Swedish but would like to repeat that whether there is a second suffix $\{-r\}$ or not does not change our claim that the plural suffix carries no accent.

There are many advantages in assuming that the indefinite plural suffix $\{-\mathrm{V} r\}$ comes with no accent, just like the infinitive, and that ONLY lexically specified morphemes can override the default disyllabic trochaic accent 2 assignment. Riad's analysis of the plural requires two suffixes $\{-\mathrm{V} r\}$ and $\{-r\}$, thus one suffix which is syllabic and one which is not. Riad's syllabic plural suffix is lexically specified for inducing accent 2. He assumes that the most common of the plural suffixes, the syllabic version, comes with a lexical high tone $\left\{-\mathrm{V} r^{\mathrm{H}}\right\}$. The other, nonsyllabic plural suffix cannot come with a high tone since, as he notes, suffixes must be 'invariably syllabic' to induce accent 2 (2003b:4). 
For Riad's analysis, stems cannot be marked for accent 1, and since the plural suffix comes with accent 2 , we should expect fänrik+ar $2>* f a ̈ n r i k a r_{2}$. To solve this problem, Riad introduces a locality constraint: 'Lexical accent 2 information can only be assigned from an inflection if it is immediately adjacent to the stress' (2003b:4). This correctly accounts for 'fänrikar ${ }_{1}$, but cannot account for forms like be'handlingar ${ }_{1}$, where in his analysis both suffixes come with accent 2: $-i n g^{2},-a r^{2}$ (Riad 1998a:83). Consider also the following examples:

$$
\begin{array}{lll}
\multicolumn{2}{l}{\text { Nominalisation in Central Swedish }} \\
\text { Verb }_{\mathrm{INF}} & \text { 'teckna } & \text { be-'teckna } \\
\text { Noun }_{\mathrm{SG}} & \text { 'tekn-ing } & \text { be-'teckn-ing } \\
\text { Noun }_{\mathrm{PL}} & \text { 'tekn-ing-ar } & \text { be-'teck-ning-ar }
\end{array}
$$

The verb 'teckna has accent 2 (stem is disyllabic) yet be'teckna has accent 1 . If a nominalising suffix is added to the simple verb root, the derived noun has accent 2 , 'teckning ${ }_{2}$ but remains accent 1 when the root is prefixed beteckning ${ }_{1}$. In addition, the plural of the respective nouns retains this accent. If we accept Riad's analysis - that the suffix $\{-i n g\}$ comes with accent 2 , and that the plural suffix $\{-a r\}$ always bears lexical accent 2 - be'teckningar should be accent 2 . Riad accounts for the accent 1 of this word as well as of be'handling (above) in his $2003 \mathrm{~b}$ talk by the deaccenting property of $\{b e-\}$ (Riad 1998a:86, fn. 29), which obviously overrides the accent marking of the noun and the suffixes: teckna 2 , -ing $g_{2},-a r_{2}$. In his $2003 \mathrm{~b}$ talk, he resolves this with his two-morpheme constraint: 'Lexical accent 2 information must occur within the first two morphemes of a structure in order to become a property of the whole structure' (2003b:4). Thus, in Riad's analysis, be'handlingar gets accent 1, because the first two morphemes $\{b e\}$ and $\{$ hand $\}$ are lexically unspecified for tone, and the lexical accent 2 information of the plural suffix gets stranded in the third morpheme, and thus the word receives default accent 1 .

In our analysis of the plural, only the lexically specified accent can override default accent 2. The plural affix $\{-\mathrm{V} r\}$ is not specified for any accent. Stems like fänrik $k_{1}$ or morphemes like $\left\{b e_{-1}\right\}$ are specified for accent 1 and will always impose their accent on any complex morphological form. No locality constraint or twomorpheme generalisations are necessary.

There is, however, a further indefinite plural suffix in Swedish which, in our

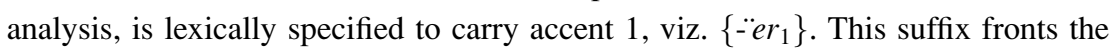
root vowel of the noun and gives it accent 1. Again, nouns need to be subcategorised for this suffix: stad, städer ${ }_{1}$, bok, böcker $_{1}$, etc.

\subsubsection{Definite article}

We follow the standard assumption that accent assignment remains unaffected by the addition of the definite article clitics $\left(\mathrm{SING}=e n / n_{\mathrm{COMMON}}=e t / t_{\mathrm{NEUTER}}\right.$; 
PLURAL $=e n / n a / a)$ in Swedish (cf. Riad 1998a:65), as we see below in (17). Based on Riad's (2003c) analysis of the definite singular clitics, we assume that the neuter clitic is a full syllable $=e t$, while the common gender singular definite clitic is only a consonant $=n$, and the vowel is inserted by epenthesis. Riad's reason for assuming this asymmetry is based on vowel final monosyllabic nouns like 'bi and 'sky, where the definite singular forms are 'biet but 'skyn and not *skyen. Under similar assumptions, we can hypothesise that the definite plural clitic has the forms $=e n$, which is only added to neuter nouns that have a zero plural as in hus and lakan, or =na elsewhere. The cliticised forms even if they are disyllabic, simply take on the accent of the word. Accordingly, there is a clear contrast between the plural suffix and the definite clitic.

Definite article vs. plural suffix in Central Swedish

a. Monosyllabic SINGULAR \& PLURAL: neuter

\begin{tabular}{lllll}
\hline SINGULAR & SING. DEF. & PluRAL & PluRAL DEF. & GlOSS \\
\hline 'hus & 'hus $=\mathrm{et}_{1}$ & 'hus- $\varnothing_{1}$ & 'hus $=\mathrm{en}_{1}$ & 'house' \\
\hline 'bi & 'bi $=\mathrm{et}_{1}$ & 'bi-n ${ }_{1}$ & 'bi-n $=\mathrm{a}_{1}$ & 'bee' \\
\hline
\end{tabular}

b. Monosyllabic SINGULAR \& disyllabic PLURAL: common gender

\begin{tabular}{lllll}
\hline Singular & SiNG. DEF. & PluRAL & PluRAL DEF. & Gloss \\
\hline 'lag & 'lag $=\mathrm{en}_{1}$ & 'lag-ar 2 & 'lag-ar $=\mathrm{na}_{2}$ & 'law' \\
\hline 'stol & 'stol $=\mathrm{en}_{1}$ & 'stol-ar 2 & 'stol-ar $=\mathrm{na}_{2}$ & 'chair' \\
\hline 'sky & 'sky $=\mathrm{n}_{1}$ & 'sky-ar 2 & 'sky-ar $=\mathrm{na}_{2}$ & 'sky' \\
\hline
\end{tabular}

c. Disyllabic SINGULAR \& PLURAL: neuter \& common gender

\begin{tabular}{lllll}
\hline SINGUlaR & SING. DEF. & PluRAL & PluRAL DEF. & GlOSS \\
\hline 'flöde & 'flöde $=\mathrm{t}_{2}$ & 'flöde- $\mathrm{n}_{2}$ & 'flöde-n $=\mathrm{a}_{2}$ & 'flow' \\
\hline 'lakan & 'lakan $=\mathrm{et}_{2}$ & 'lakan- $\varnothing_{2}$ & 'lakan $=\mathrm{en}_{2}$ & 'sheet' \\
\hline 'flicka & 'flicka $=\mathrm{n}_{2}$ & 'flick-or 2 & 'flick-or $=\mathrm{na}_{2}$ & 'girl' \\
\hline 'gubbe & 'gubbe $=\mathrm{n}_{2}$ & 'gubb-ar & 'gubb-ar $=\mathrm{na}_{2}$ & 'old man' \\
\hline
\end{tabular}


d. Disyllabic (lexically specified accent 1) SINGULAR \& PLURAL: neuter \& common gender

\begin{tabular}{lllll}
\hline SINGULAR & SING. DEF. & PLURAL & PLURAL DEF. & GLOSS \\
\hline termos $_{1}$ & 'termos $=\mathrm{en}_{1}$ & 'termos-ar & 'termos-ar $=$ na $_{1}$ & 'thermos' \\
\hline pentry $_{1}$ & 'pentry $=\mathrm{t}_{1}$ & 'pentry-n & 'pentry $=$ na $_{1}$ & 'pantry' \\
\hline
\end{tabular}

The monosyllabic word 'hus receives accent 1 postlexically since a minimum of two syllables are required for the realisation of accent 2 . The definite article enclitic $=e t$

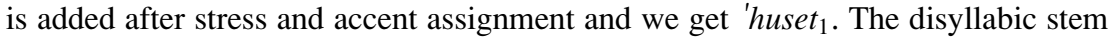
flicka receives accent 2 postlexically, which is not affected by the addition of the definite article $=n$.

(18) Analysis of definite article (singular) enclitics in Central Swedish

ACCENT ASSIGNMENT in word domain

\begin{tabular}{|c|c|c|c|}
\hline LEXICAL & STRESS \& & CLITICISATION \& & \\
\hline REPRESENTATION & ACCENT ASSIGN. & EPENTHESIS & \\
\hline /hus/ & 'hus ${ }_{1}$ & 'hus $_{1}=$ et & 'huset $_{1}$ \\
\hline /lag/ & 'lag 1 & 'lag $1=\mathrm{n}$ & 'lagen $_{1}$ \\
\hline /flicka/ & 'flicka2 & 'flicka $2=\mathrm{n}$ & 'flickan 2 \\
\hline$/$ termos $_{1} /$ & 'termos $_{1}$ & termos $_{1}=\mathrm{n}$ & 'termosen 1 \\
\hline
\end{tabular}

If the plural suffix is added (cf. (19) below), 'flickor again receives default accent 2 postlexically and remains unchanged when the definite clitic is added. Although termos is a disyllabic trochaic stem, it comes with lexical accent 1 and differs in its behaviour from 'flicka. Neither the addition of the plural nor the addition of the definite article has any effect on the lexical accent assignment which remains accent 1 as we see in (19).

(19) Analysis of definite article (plural) enclitics in Central Swedish

\begin{tabular}{|c|c|c|c|c|}
\hline LEXICAL & & STRESS \& & & \\
\hline REPRESENTATION & PLURAL & ACCENT ASSIGN. & CLITICISATION & \\
\hline /hus/ & 'hus- $\varnothing$ & 'hus 1 & 'hus $_{1}=$ en & 'husen 1 \\
\hline /lag/ & 'lag-ar & 'lagar 2 & ${ }^{\prime} \operatorname{lagar}_{2}=$ na & 'lagarna 2 \\
\hline /flicka/ & 'flick-or & 'flickor 2 & ${ }^{\prime}$ flickor $_{2}=$ na & 'flickorna 2 \\
\hline$/$ termos $_{1} /$ & 'termos 1 -ar & 'termosar 1 & termosar $_{1}=$ na & 'termosarna 1 \\
\hline
\end{tabular}

Until now our analysis has focussed on prefixes specified for accent 1 such as $\{b e-1\}$ and $\left\{f_{0} r_{-1}\right\}$. In general, most affixes need not be specified for any accent whatsoever and the regular accent assignment rule would assign word accent based on any other specified accent in the morphological structure of the word. As far as we can see, inflectional suffixes never carry lexical tone; only derivational affixes can be specified for accent 1 . Here we list some suffixes with and without accent 1 : 
(20)

More Central Swedish affixes

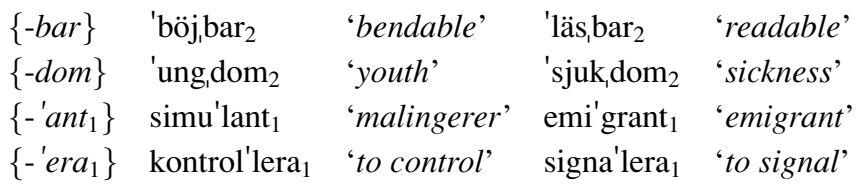

Words like läsbar are assigned accent 2 postlexically. In contrast, words ending in a final stressed syllable like emi'grant would get accent 1 since there is no disyllabic trochee to host accent 2 . The suffix $\left\{-\right.$ ' $\left.^{\prime} \mathrm{Ant}_{1}\right\}$ must bear accent 1 since the plural forms of all nouns with this suffix have accent 1 , cf. emi'granter 1 . Suffixes like $\{-$ 'era $\}$, however, differ. The infinitival forms of these verbs have full vowels, end in a trochee, and thus there is no reason why they should not otherwise have accent 2. In our analysis, just like the prefix $\{b e-1\}$ bears accent 1 , the suffix $\left\{-{ }^{\prime}\right.$ er $\left.a_{1}\right\}$ is also specified for accent 1 . Accent 1 dominates and all $\left\{-\right.$ 'era $\left._{1}\right\}$ verbs have accent 1 in the infinitive.

Our analysis of Standard East Norwegian is in many ways similar to that of Central Swedish. We again claim that only morphemes with lexical accent 1 are specified and lexical accent overrides any postlexical accent assignment. One major difference between Central Swedish and Standard East Norwegian, however, is that of the specification of accent 1 for stressed prefixes. We turn to this below in section 3.2 .

\subsection{Synchronic analysis of Standard East Norwegian}

Our analysis of Standard East Norwegian is basically identical to that of Central Swedish, viz. only lexical specification of accent 1 is allowed. In what follows, however, we discuss derivational affixes, the present tense, inflectional suffix and plural suffixes and clitics, pointing out the differences between the two languages.

\subsubsection{Stressed \& unstressed prefixes in Standard East Norwegian}

Central Swedish and Standard East Norwegian differ in their tonal make-up of morphologically complex words in respect to some stressed and unstressed prefixes. Compare the following verbs and their accents:

\begin{tabular}{|c|c|}
\hline SWEDISH & NORWEGIAN \\
\hline 'falla 2 & 'falle 2 \\
\hline be'falla & be'fale $_{1}$ \\
\hline 'anbe,falla 2 & 'anbe,fale ${ }_{1}$ \\
\hline 'an,falla 2 & 'an,falle 1 \\
\hline 'över,tala 2 & 'overtale ${ }_{2}$ \\
\hline
\end{tabular}


As Riad (1998a) asserts, stressed prefixes in Central Swedish behave like compounds and these prefixed words always bear accent 2. The compound rule for Central Swedish is given in (22).

(22) Accent assignment in Central Swedish stressed and unstressed prefixed words and compounds

Compound rule: ' $\omega \omega \rightarrow$ accent 2

$$
\begin{array}{ll}
\left(\left\{\text { be } e_{1}\right\}\{\text { 'fall-a }\}\right)_{\omega} & \text { Lexical accent } 1 \text { dominates } \\
(\{\text { 'an }\})_{\omega}(\{\text { fall-a }\})_{\omega} & \text { Compound accent } 2 \\
\left.(\{\text { 'an }\})_{\omega}\left(\left\{\text { be } e_{1}\right\}\{\text { fall-a }\}\right)\right)_{\omega} & \text { Compound accent } 2 \\
(\{\text { 'over }\})_{\omega}(\{\text { 'tala }\})_{\omega} & \text { Compound accent } 2
\end{array}
$$

This does not follow for Standard East Norwegian. Stress does not automatically determine accent: compare 'anfalle 1 and 'overtale ${ }_{2}$. We claim that Standard East Norwegian differs from Central Swedish in that stressed prefixes may also bear accent 1 , and as before, whenever there is a lexically specified accent 1 prefix, the whole word has to be accent 1 . Whether a stressed prefix behaves as a prosodic word or not is dealt with in section 4 .

$$
\begin{aligned}
& \text { Analysis of complex verbs in Standard East Norwegian } \\
& \begin{array}{lc}
\left(\left\{b e_{1}\right\}\{\text { fal-e }\}\right) & \text { Lexical accent } 1 \text { dominates } \\
\left(\left\{\text { I }_{1}\right\}\right)(\{\text { fall-e }\}) & \text { Lexical accent } 1 \text { dominates } \\
\left(\left\{\text { an }_{1}\right\}\right)\left(\left\{b e_{1}\right\}\{\text { fal-e }\}\right) & \text { Lexical accent } 1 \text { dominates }
\end{array}
\end{aligned}
$$

Standard East Norwegian differentiates certain verbal and nominal prefixes in terms of accent marking. The stressed prefixes $\{\mathrm{om}-\}$ and $\{a n-\}$ come with lexical accent 1 when added to verbs but not when added to nouns. The divergence between our postulation and Withgott \& Halvorsen's $(1984,1988)$ is that for us only the verbal prefix is lexically specified for accent 1 ; the noun simply gets accent 2 postlexically.

\section{Nominal and verbal prefixes in Standard East Norwegian}

Lexical representation: /-e/INF, /om $1-/ \mathrm{v}, / \mathrm{om}-\mathrm{N}_{\mathrm{N}}, / \mathrm{an}_{1}-/ \mathrm{v}, / \mathrm{an}-\mathrm{N}_{\mathrm{N}}$

$\begin{array}{llll}\text { /tale/ } & \text { postlexical accent } & \text { 'tale } & \text { 'talk' } \\ \text { /tal//e/ } & \text { postlexical accent } & \text { 'tale } & \text { 'to talk' } \\ \text { /om } / / \text { tal//e/ } & \text { lexical accent } 1 \text { dominates } & \text { 'omtale } & \text { 'to discuss' } \\ \text { /om//tale/ } & \text { postlexical accent } & \text { 'omtale }_{2} & \text { 'report' } \\ \text { /klag//e/ } & \text { postlexical accent } & \text { 'klage } 2 & \text { 'to complain' } \\ \text { /an } / / / \mathrm{klag} / / \mathrm{e} / & \text { lexical accent } 1 \text { dominates } & \text { 'anklage } 1 & \text { 'to accuse' } \\ \text { /an//klage/ } & \text { postlexical accent } & \text { 'anklage } 2 & \text { 'accusation' } \\ \text { /klage/ } & \text { postlexical accent } & \text { 'klage } 2 & \text { 'complaint' }\end{array}$


The next obvious comparison to be made with Central Swedish is present tense marking. Unlike in Swedish, the surface present tense ending is always [-er] in Standard East Norwegian. This is because, as we saw before, Norwegian neutralised the final a/e contrast, and disyllabic Swedish roots like tala are monosyllabic tal in Norwegian. The monosyllabicity of these roots is attested by the imperatives in Norwegian, which are also monosyllabic. However, the Swedish contrast in the present tense between 'talar 2 and 'stämmer ${ }_{1}$ is also maintained in Norwegian, not with epenthetic $e$ as in Swedish 'stämmer $r_{1}$ but through allomorphy in the suffix. On the surface, in Norwegian, the present tense marker $\{-e r\}$ has ambiguous accent marking. Consider the following alternations in Norwegian given in Withgott \& Halvorsen (1984:22):

Standard East Norwegian present tense $\{-\mathrm{er}\}$

\begin{tabular}{|c|c|c|c|c|c|}
\hline INFINITIVE & PRESENT & GLOSS & INFINITIVE & PRESENT & GLOSS \\
\hline 'spise 2 & 'spiser $_{1}$ & 'eat' & 'knise 2 & 'kniser 2 & 'giggle' \\
\hline '1øpe & 'løper & 'run' & 'kjøpe ${ }_{2}$ & 'kjøper 2 & ‘buy’' \\
\hline 'ete 2 & 'eter ${ }_{1}$ & 'eat' & 'hete 2 & 'heter 2 & 'to be called' \\
\hline
\end{tabular}

Given Withgott \& Halvorsen's analysis, verb roots like knis have a floating H or accent 2, which automatically induces accent 2 in the present tense. Kristoffersen (2000:263), on the other hand, claims that the allomorphy is in the suffix and not in the root. Therefore, in his analysis there are two suffixes, one with a floating $\mathrm{H}$ or accent 2 and one without tone. Thus, the tone-bearing suffix which is added to roots like knis, has a floating high tone, $\left\{-e r^{\mathrm{H}}\right\}$ while its counterpart $\{-r\}$ that is added to spis does not. From our perspective, the present tense suffix does indeed have two allomorphs, but they differ segmentally and not tonally: $\{-e r\}$ and $\{-r\}$. We follow Kristoffersen's (2000:263) analysis in saying that the consonantal suffix $\{-r\}$ adds to verbs like /spis-r/ and surfaces with an epenthetic vowel, thereby being assigned accent 1 for a monosyllabic word first. Therefore, like Kristoffersen, we assume a consonantal suffix. However, his syllabic present tense suffix is lexically specified for tone. For our analysis, the suffix $\{-e r\}$ merely adds a syllable to roots like knis such that the present tense 'kniser gets accent 2 postlexically.

Again, if the unstressed prefix $\left\{b e_{-1}\right\}$ is added, we get a different picture. Regardless of the unprefixed forms, the present tense of be 'spise 1 will be accent 1 (be'spiser ${ }_{1}$ ). Further evidence for the lexical specification of accent 1 comes from compounds. Before we turn to compounds, however, we give the accent assignment details for Standard East Norwegian below.

\subsubsection{Indefinite plural in Standard East Norwegian}

Recall that in Swedish the present tense suffix was $\{-r\}$ and the overall pattern of the indefinite plural suffix was $\{-\mathrm{V} r\}$. Standard East Norwegian, as we have seen, has 
two allomorphs of the present tense suffix: $\{-e r\}$ and $\{-r\}$. Is there a need for two allomorphs in the indefinite plural as well?

On the contrary, the indefinite plural in Standard East Norwegian is similar to Swedish in that it has one plural suffix $\{-\mathrm{V} r\}$; however, the vowel in Standard East Norwegian always surfaces as $\{-e r\}$, as we see in (26). ${ }^{9}$

\section{Indefinite plural in Standard East Norwegian}

\begin{tabular}{|c|c|c|c|}
\hline & LEXICAL & SINGULAR & PLURAL \\
\hline a. & /hest/ /er/ & 'hest & 'hester > 'hester 2 \\
\hline b. & /månad/ /er/ & 'måned 2 & 'måneder > 'måneder 2 \\
\hline c. & /pike/ /er/ & pike $_{2}$ & 'piker $>$ 'piker 2 \\
\hline $\mathrm{d}$. & /opera 1 / /er/ & 'opera $_{1}$ & 'opera $_{1}$ er $>$ 'operaer $_{1}$ \\
\hline e. & /studie 1 / /er/ & 'studie $_{1}$ & 'studie $_{1}$ er $>$ 'studier 1 \\
\hline f. & /fenrik $/$ / /er/ & 'fenrik 1 & 'fenrik $_{1}$ er $>$ 'fenriker 1 \\
\hline g. & /hand//ling/ /er/ & 'handling 2 & 'handlinger $>$ 'handlinger 2 \\
\hline h. & /be ${ }_{1} / /$ handling/ /er/ & be'handling & be $_{1}$ 'handlinger $>$ be'handlinger $_{1}$ \\
\hline i. & /åkr/ /er/ & 'åker 1 & 'åkrer > åkrer 2 \\
\hline j. & /himmel/ /er/ & 'himmel 2 & 'himmeler > 'himler, \\
\hline $\mathrm{k}$. & $/ \mathrm{regl}_{1} / / \mathrm{er} /$ & 'regel $_{1}$ & 'regl $_{1}$ er $>$ 'regler 1 \\
\hline 1. & /student $1 /$ /er/ & stu'dent $_{1}$ & stu'dent $_{1}$ er $>$ stu'denter $_{1}$ \\
\hline $\mathrm{m}$. & /generator 1 / /er/ & gene'rator $_{1}$ & 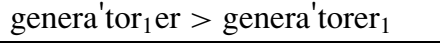 \\
\hline $\mathrm{n}$. & /professor $1 /$ /er/ & pro'fessor $_{1}$ & profes'sor $_{1} \mathrm{er}>$ profes'sorer $_{1}$ \\
\hline o. & $/ \mathrm{sko}_{1} / / \varnothing /$ & sko $_{1}$ & $\mathrm{sko}_{1}>$ 'sko $_{1}$ \\
\hline
\end{tabular}

As we have seen in Swedish, there are basically four scenarios: (i) stems may be specified for tone and thus have accent 1 in the singular and plural as in student $t_{1}$, stu'denter $_{1}$ (cf. (26d, e, f, k, 1, m, n)); (ii) there are words that do not consist of a disyllabic trochee in the singular and therefore have accent $1 / a \mathrm{kr} /$ in the singular and accent 2 in the plural (cf. (26i)); (iii) other words consist of a disyllabic trochee in the singular, like 'himmel, are unspecified for tone, and thus have default accent 2 in the singular and plural (cf. (26j)); and finally, (iv) in Norwegian as in Swedish there is an indefinite plural suffix that fronts the root vowel of the noun and is specified for accent $1,\left\{\ddot{-e} r_{1}\right\}$. Nouns will be subcategorised in the lexicon for having this suffix: bok, boker 1 , etc.

In Kristoffersen's analysis of the indefinite plural, once again, an inflectional suffix is lexically specified. As in the present tense, he assumes the plural suffix: $\left\{-r^{\mathrm{H}}\right\}$ carries a high tone (he also needs a toneless suffix $\{-r\}$ to account for the umlauted plurals). In addition to a lexically specified suffix, Kristoffersen also requires a phonological constraint, i.e. locality constraint, and a morphological constraint. The locality constraint, analogous to Rischel (1963/1983:270), Haugen (1967/1983:299) 
and Riad (2003b), who also assume a plural suffix bearing a high tone, has to account for the restriction that if the stem consists of more than one syllable, the tonal properties of the stem take precedence' (Kristoffersen 2000:258). The LOCALITY CONSTRAINT confines the lexical high tone's range to the preceding syllable. Thus, the $\mathrm{H}$ of the suffix 'can only associate with the final syllable of the stem' (ibid) if it is stressed. This constraint would explain the accent 1 in $(26 \mathrm{~d}, \mathrm{e}, \mathrm{f}, \mathrm{k}, 1, \mathrm{~m}, \mathrm{n}$,) for Kristoffersen. However, cases with stem final stress like pi 'lot ${ }_{1}$, pi 'loter ${ }_{1}$, present more difficulties for him. For us, the stem pilot $_{1}$ is lexically marked, and all is said accent 1 prevails. Kristoffersen, however, needs a MORPHOLOGICAL CONSTRAINT on the tonal foot here, to the effect that 'a tonal foot built by a morphological rule can. . . only occur at the left edge of a prosodic word' (Kristoffersen 2000:260). Recall that this is the morphological constraint that Kristoffersen needs to ensure accent 1 for prefixed infinitives as well. ${ }^{10}$

To sum up, Kristoffersen's analysis of the indefinite plural consists of a lexically specified indefinite plural suffix, and two constraints, the effects of which are graphically illustrated in (27).

\section{Kristoffersen's $H$ linking in the indefinite plural}

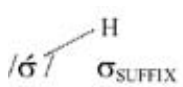

$$
\text { /hest } / / \mathrm{r}^{\mathrm{H}} />\text { hester } 2
$$

( ${ }^{\mathrm{H}}$ of stem survives)

\section{LOCALITY CONSTRAINT}

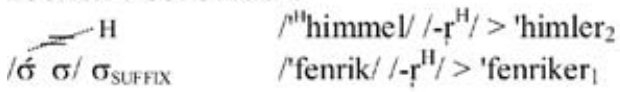

\section{( ${ }^{\mathrm{H}}$ of suffix does not associate)}

\section{MORPHOLOGICAL CONSTRAINT}

$$
/ \sigma \sigma / \sigma_{\text {SUFIX }} \quad \text { /pi'lot } / /-\mathrm{r}^{\mathrm{H}} />\text { pi'loter }_{1}
$$

Thus, the effect of the $\mathrm{H}$ of $\left\{-r^{\mathrm{H}}\right\}_{\text {INDEF.PL }}$ is observable only on monosyllabic roots like /hest/. In contrast, our analysis involves an indefinite plural suffix that is not lexically specified for accent and the general assertion that lexically specified accent 1 will prevail when present.

Following Rischel (1963/1983:271f.), Haugen (1967/1983:299) and Kristoffersen (2000:258), we assume that stems like /åkr/ and /fingr/ are monosyllabic and lexically unspecified, and thus have accent 2 plurals. However, as we have posited, if a stem is lexically specified for accent 1 , this accent will prevail. Thus, adding an indefinite plural suffix or any other suffix to a lexically specified stem should not change the accent - it should remain accent 1 in the plural as well. This we have seen many times over with polysyllabic stems. Although evidence for this hypothesis is difficult to come by, since most lexically marked monosyllabic words are neuters and have zero plurals, there are other monosyllabic stems with epenthetic vowels, such as 
in the words 'sykkel 1 'bicycle', 'seddel 1 'note', 'tittel $l_{1}$ 'title' and 'middel 1 'middle', which all have accent 1 in the plural ('sykler 1 , 'sedler ${ }_{1}$, 'titler ${ }_{1}$, 'midler ${ }_{1}$ ). In our analysis, these nominal stems are specified for accent 1 , which becomes apparent when they constitute the first member of a compound ('sykkel,klokke ${ }_{1}$, 'seddel,bok , $_{1}$, 'tittel blad $_{1}$, 'middel alder $_{1}$ ). When we take a closer look at the compounds in section 4, we will find more evidence that monosyllabic words can also be lexically specified for tone. First, let us formulate an initial approximation of lexical accent marking in Standard East Norwegian.

(28) Lexical accent marking in Standard East Norwegian (initial approximation)

Lexical accent 1 [No morpheme or word bears accent 2 lexically]

Words with lexical accent 1: 'fenrik $k_{1}$ 'ensign', 'sykkel $1_{1}$ 'bike', pro'fessor 1 'professor', gene 'rator 1 'generator', etc.

names of places: $\quad$ 'Bergen $1, A^{\prime}$ merika $_{1}$, etc.

days of the week: 'lordag $\quad$ 'Saturday', 'mandag ${ }_{1}$, 'Monday', etc.

Prefixes:

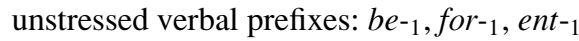
stressed verbal prefixes: ' $a n_{1^{-}},{ }^{\prime} a v_{1^{-}},{ }^{\prime}{ }^{\prime} m_{1}$ -

Suffixes: -'ere 1 , etc.

(29) Accent assignment in Standard East Norwegian (identical to (10) above, for Central Swedish)

a. Accent 1 is lexically specified on morphemes

b. Postlexical accent assignment (if not lexically specified)

$$
\begin{array}{ll}
\{\ldots \dot{\sigma} \sigma \ldots\}_{\omega} & \rightarrow \text { accent } 2 \\
\{\ldots\}_{\omega} & \rightarrow \text { accent } 1
\end{array}
$$

Until now, the only difference we have seen in accent assignment between Central Swedish and Standard East Norwegian is that the latter may have stressed prefixes, or particles carrying lexical accent 1 . As we will see in the next section, this sort of lexical specification is also carried over in compounds.

\section{COMPOUNDS}

The Scandinavian dialects show interesting variation with respect to accent 1 assignment in compounds. We repeat the table below from Perridon (2003):

(30) Possible occurrence of accent 1 in compounds and particle verbs

$\begin{array}{llll}\text { EAST } & \text { SOUTH } & \text { CENTRAL } \\ \text { NORWEGIAN } & \text { SWEDISH } & \text { DANISH } & \text { SWEDISH }\end{array}$

$\begin{array}{lllll}\text { Compounds } & \text { Yes } & \text { Yes } & \text { Yes } & \text { No } \\ \text { Particle verbs } & \text { Yes } & \text { Yes } & \text { Yes } & \text { No }\end{array}$


In both East Norwegian and dialects of Southern Swedish, compounds may have either accent 1 or accent 2 (Bruce 1973, 1974). Riad (2003b) refers to these dialects as being innovative and Central Swedish as being conservative, because here compounds always have accent 2 . Perridon (2003), however, sees it differently: 'Central Swedish radically simplified the stress and accent system of the compounds, by giving them all accent 2'. This follows from our analysis as well.

Synchronically, as we mentioned above, we follow Riad in assuming that Central Swedish compounds are analyzed as two prosodic words and that they receive compound accent 2 . Recall that Central Swedish also only allows accent 2 in words with stressed prefixes (or particles). Lexical accent 1, in our terms, plays no role in Central Swedish compound constructions. Norwegian compounds, however, like their prefixed verbs, come in various accent combinations, and unlike Central Swedish, they can sustain both accent 1 and 2 . If the compounds are organised according to the number of syllables of the first element, we can see that almost all possibilities are available, as in (31).

\section{(31) Norwegian compounds}

a. Polysyllabic first element with accent 1 and 2

\begin{tabular}{|c|c|c|c|}
\hline FIRST ELEMENT & SECOND ELEMENT & COMPOUND & GLOSS OF COMPOUND \\
\hline \multirow[t]{3}{*}{ 'kirke 2} & 'tårn & 'kirke,tårn, 2 & 'church tower' \\
\hline & 'orgel $_{1}$ & 'kirke,orgel 2 & 'church organ' \\
\hline & 'tjener 2 & 'kirke,tjener 2 & 'sexton' \\
\hline \multirow[t]{3}{*}{ 'aksje $_{1}$} & 'bank 1 & 'aksje,bank 1 & 'stock bank' \\
\hline & 'kapital 1 & 'aksjekapi,tal 1 & 'stock capital' \\
\hline & marked $_{2}$ & 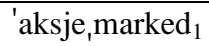 & 'stock market' \\
\hline
\end{tabular}

b. Monosyllabic first element with accent 1 and 2

\begin{tabular}{|c|c|c|c|}
\hline FIRST ELEMENT & SECOND ELEMENT & COMPOUND & GLOSS OF COMPOUND \\
\hline \multirow[t]{3}{*}{ 'land 1} & 'kart 1 & 'land,kart 2 & 'map' \\
\hline & 'tunge 2 & 'land,tunge ${ }_{2}$ & 'peninsula' \\
\hline & 'handel 1 & 'land,handel 2 & 'general store' \\
\hline \multirow[t]{3}{*}{ sko $_{1}$} & 'krem 1 & 'sko,krem 1 & 'shoe cream' \\
\hline & 'såle 2 & 'sko,såle 1 & 'sole of a shoe' \\
\hline & fa'brikk $_{1}$ & 'skofa,brikk 1 & 'shoe factory' \\
\hline
\end{tabular}


The accent of each independent form of the first and second elements is given in columns 1 and 2. Compounds with a polysyllabic first member (31a) appear to be transparent. The compound accent is the same as that of the initial member and is independent of the syllabic makeup of the second member. Thus, both 'aksjemarked 1 and 'aksjekapi,tal ${ }_{1}$ have accent 1 regardless of the accent of the second member.

Compounds with monosyllabic first elements are not as obvious. Since monosyllabic words must surface with accent 1 , if the initial member dominated the accent, the accent of the whole compound should always be accent 1 . Nevertheless, we get alternations like 'skokrem with accent 1 , but 'landkart with accent 2 . It is neither the number of syllables of the second member, nor the accent of the second member that appear to be the deciding factor. Kristoffersen (2000:264) provides a very nice example of the homophone ball meaning 'round object' or 'large social dance' which manifest different accent patterns in compounding (cf. (32)). For example, 'ballssal is accent 1 , but 'ballsspill has accent 2 .

Accent 1 and 2 realisations of ball (from Kristoffersen 2000)

\begin{tabular}{llll}
\hline ACCENT 1 & GLOSS & ACCENT 2 & GLOSS \\
\hline ball $_{1}$ sal $_{1}$ & 'ballroom' & ball $_{1}$ spill $_{1}$ & 'ball game' \\
\hline ball $_{1}$ kjole $_{2}$ & 'ball gown' & ball $_{1}$ trening $_{2}$ & 'ball training' \\
\hline
\end{tabular}

Withgott \& Halvorsen (1984) and Kristoffersen (2000) all emphasise that for the polysyllabic first members, the accent of the first word induces the accent of the compound. However, the problem for both lies with monosyllabic initial words (cf. ball 'round object') or certain words ending in sonorants, such as 'finger, which should induce accent 1 but instead result in accent 2 compounds. Withgott \& Halvorsen suggest for these words that a floating High tone (or accent 2) is a part of the lexical representation of these roots, and subsequently induces accent 2 in compounds. Thus, in their analysis, the word land in 'land kart 2 would have a floating accent 2. Kristoffersen argues against this analysis, because the floating accent 2 of these words would only emerge in compounds. Instead, he argues that accent 2 is not an essential part of any of these individual words, but rather that these accent-2-inducing monosyllabic first elements have a 'compound stem' with a floating High tone. This representation is given in (33).

\section{Kristoffersen's (2000:266) floating H for compounds} $\mathrm{H}$

$$
\left[[\mathrm{X}]_{\mathrm{N}, \mathrm{A}}\right]_{\text {COMPOUND STEM }}\left[[\mathrm{land}]_{\mathrm{N}}\right]^{\mathrm{H}} \text { COMPOUND STEM }
$$


This $\mathrm{H}$ will be part of the analysis of words which surface as accent 1 in the singular but induce accent 2 in compounds, and will be in the 'underlying representations of all stems that induce accent 2 without further formal modification of the stem' (Kristoffersen 2000:266). Thus, this representation will be both inherent to ball 'round object' and land, and both will trigger accent 2 in compounds. ${ }^{11}$ In (34), we show what the underlying representation would be like within Kristoffersen's analysis.

(34) Kristoffersen's analysis: accent of first element determines accent of compound a. Polysyllabic first element with accent 1 and 2

\begin{tabular}{|c|c|c|c|c|}
\hline $\begin{array}{l}\text { LEXICAL } \\
\text { REPRESENTATION }\end{array}$ & $\begin{array}{l}\text { FIRST } \\
\text { ELEMENT }\end{array}$ & $\begin{array}{l}\text { SECOND } \\
\text { ELEMENT }\end{array}$ & COMPOUND & $\begin{array}{l}\text { GLOSS OF } \\
\text { COMPOUND }\end{array}$ \\
\hline \multirow[t]{3}{*}{${ }^{\mathrm{H}}$ kirke } & 'kirke $_{2}$ & 'tårn' & 'kirke,tårn 2 & 'church tower' \\
\hline & & 'orgel $_{1}$ & 'kirke, orgel & 'church organ' \\
\hline & & 'tjener $_{2}$ & 'kirke,tjener ${ }_{2}$ & 'sexton' \\
\hline \multirow[t]{3}{*}{ aksje } & 'aksje $_{1}$ (default) & 'bank 1 & 'aksje,bank 1 & 'stock bank' \\
\hline & & 'kapital $_{1}$ & 'aksjekapi,tal $_{1}$ & 'stock capital' \\
\hline & & marked $_{2}$ & 'aksje,marked $_{1}$ & 'stock market' \\
\hline
\end{tabular}

b. Monosyllabic first element with accent 1 and 2

\begin{tabular}{|c|c|c|c|c|}
\hline $\begin{array}{l}\text { LEXICAL } \\
\text { REPRESENTATION }\end{array}$ & $\begin{array}{l}\text { FIRST } \\
\text { ELEMENT }\end{array}$ & $\begin{array}{l}\text { SECOND } \\
\text { ELEMENT }\end{array}$ & COMPOUND & $\begin{array}{l}\text { GLOSS OF } \\
\text { COMPOUND }\end{array}$ \\
\hline \multirow[t]{3}{*}{ land $[\mathrm{H}]_{\text {CompStem }}$} & 'land ${ }_{1}$ & 'kart & 'land,kart, & 'map' \\
\hline & & 'tunge ${ }_{2}$ & 'land,tunge 2 & 'peninsula' \\
\hline & & 'handel 1 & 'land,handel 2 & 'general store' \\
\hline \multirow[t]{3}{*}{ sko } & 'sko 1 (default) & 'krem 1 & 'sko,krem 1 & 'shoe cream' \\
\hline & & 'såle 2 & 'sko,såle ${ }_{1}$ & 'sole of a shoe' \\
\hline & & fa'brikk $_{1}$ & 'skofa,brikk 1 & 'shoe factory' \\
\hline
\end{tabular}

Note that for Kristoffersen and Withgott \& Halvorsen, it is the initial member of the compound that dominates the accent assignment, and it is lexical accent 2 that does all the work, be it floating or a part of the compound stem.

Our analysis is different. We need no floating $\mathrm{H}$ for any stem specifically for compounding, as do Withgott \& Halvorsen, nor do we require a floating $\mathrm{H}$ as a tonal morpheme belonging to a compound stem for specific monosyllabic words. The 
regular compound rule is the same as for Swedish, viz. that compounding leads to accent 2 . The difference is that the same assumptions hold concerning the dominance of lexically specified accent 1 for particle words in Norwegian.

(35) Norwegian compounds: our analysis

Specified lexical accent of initial word determines compound accent. Else, compound accent $=$ accent 2 .

a. Polysyllabic first element with accent 1 and 2

\begin{tabular}{|c|c|c|c|c|}
\hline $\begin{array}{l}\text { LEXICAL } \\
\text { REPRESENTATION }\end{array}$ & $\begin{array}{l}\text { FIRST } \\
\text { ELEMENT }\end{array}$ & $\begin{array}{l}\text { SECOND } \\
\text { ELEMENT }\end{array}$ & COMPOUND & $\begin{array}{l}\text { GLOSS OF } \\
\text { COMPOUND }\end{array}$ \\
\hline \multirow[t]{3}{*}{ /kirke/ } & 'kirke 2 & 'tårn 1 & 'kirke,tårn, & 'church tower' \\
\hline & & 'orgel $_{1}$ & 'kirke,orgel 2 & 'church organ' \\
\hline & & tjener $_{2}$ & 'kirke,tjener 2 & 'sexton' \\
\hline \multirow[t]{3}{*}{ aksje $_{1} /$} & 'aksje $_{1}$ & 'bank 1 & 'aksje,bank 1 & 'stock bank' \\
\hline & & kapi'tal $_{1}$ & 'aksjekapi,tal 1 & 'stock capital' \\
\hline & & marked $_{2}$ & 'aksje,marked $_{1}$ & 'stock market' \\
\hline
\end{tabular}

b. Monosyllabic first element with accent 1 and 2

\begin{tabular}{|c|c|c|c|c|}
\hline $\begin{array}{l}\text { LEXICAL } \\
\text { REPRESENTATION }\end{array}$ & $\begin{array}{l}\text { FIRST } \\
\text { ELEMENT }\end{array}$ & $\begin{array}{l}\text { SECOND } \\
\text { ELEMENT }\end{array}$ & COMPOUND & $\begin{array}{l}\text { GLOSS OF } \\
\text { COMPOUND }\end{array}$ \\
\hline \multirow[t]{3}{*}{ /land/ } & 'land ${ }_{1}$ & 'kart 1 & 'land,kart, & 'map' \\
\hline & & 'tunge ${ }_{2}$ & 'land,tunge $_{2}$ & 'peninsula' \\
\hline & & 'handel 1 & 'land,handel 2 & 'general store' \\
\hline \multirow[t]{3}{*}{$/ \mathrm{sko}_{1} /$} & 'sko $_{1}$ & 'krem, & 'sko,krem 1 & 'shoe cream' \\
\hline & & 'såle 2 & 'sko,såle 1 & 'sole of a shoe' \\
\hline & & fa'brikk 1 & 'skofa,brikk 1 & 'shoe factory' \\
\hline
\end{tabular}

In (35), we show how lexical accent specifications dominate accent assignment. Thus, we see that if the first word bears lexically specified accent 1 , the compound bears accent 1 as well; otherwise, regardless of the number of syllables and the accent of individual words, compounds are all accent 2, as in Central Swedish.

The polysyllabic word ' $a k s j e_{1}$ is lexically specified for accent 1 and determines the accent of the compounds 'aksje, marked $_{1}$ and 'aksjekapi, tal $_{1}$. The polysyllabic first element 'kirke, however, comes with no accent and thus this word receives postlexical 
accent 2 as do the compounds formed with this word as the initial member. An advantage of our analysis is that no floating compound stem accent is necessary (cf. Kristoffersen 2000), nor does it require any special floating accent for individual words during compound formation (cf. Withgott \& Halvorsen 1984). We assume that all initial members specified for lexical accent, monosyllabic or disyllabic will dominate whether in affixation or in compounding. The compound accenting rule for Norwegian is formalised in (36).

\section{Compound accent in Standard East Norwegian}

$\left[\omega_{1} \omega\right] \rightarrow$ accent 1 (first word is lexically specified)

else, $[\omega \omega] \rightarrow$ accent 2 (like Central Swedish)

Our compound accenting rule implies that in Standard East Norwegian there is a contrast between lexically specified accent 1 monosyllables and 'normal' monosyllabic words which have accent 1 simply because they do not have a disyllabic trochee. Notice that the ball 'dance' is specified for accent 1 and is always accent 1, while ball 'round object' is not lexically specified and merely receives accent 1 because it is monosyllabic and thus receives accent 2 when an additional syllable is added, e.g., in the plural and when it comprises the first element of a compound.

A further advantage is that surface disyllabic words which end in syllabic consonants need no extra comment. Consider the words in (37) within Kristoffersen's analysis.

Initial words ending in syllabic sonorants: Kristoffersen's analysis

\begin{tabular}{|c|c|c|c|c|}
\hline $\begin{array}{l}\text { COMPOUND } \\
\text { STEM }\end{array}$ & $\begin{array}{l}\text { FIRST } \\
\text { ELEMENT }\end{array}$ & $\begin{array}{l}\text { SECOND } \\
\text { ELEMENT }\end{array}$ & COMPOUND & $\begin{array}{l}\text { GLOSS OF } \\
\text { COMPOUND }\end{array}$ \\
\hline$\left[\mathrm{fIy} \cdot \mathrm{yr}_{\mathrm{r}}\right]_{\mathrm{CompStem}}^{\mathrm{H}}$ & 'finger 1 & 'ring 1 & 'finger,ring 2 & 'finger ring' \\
\hline [sœp.pl $]_{\text {CompStem }}^{\mathrm{H}}$ & 'søppel & 'kasse ${ }_{2}$ & 'søppel,kasse 2 & 'trash can' \\
\hline [has.s1 $]_{\text {CompStem }}^{\mathrm{H}}$ & 'hassel 1 & 'nøtt & 'hassel,nøtt ${ }_{2}$ & 'hazel nut' \\
\hline [ti:.gr] & 'tiger $_{1}$ & sprang $_{1}$ & 'tiger,sprang 1 & 'tiger attack' \\
\hline [ka:.bl] & 'kabel & 'bane 2 & 'kabel,bane ${ }_{1}$ & 'cable car' \\
\hline
\end{tabular}

The initial members of these compounds have accent 1 as independent words. For Kristoffersen (2000:267), the accent-2-inducing first members have to be accounted for by assuming that the statement in (33) must be part of their lexical representation. Kristoffersen (2000:266) notes that accent assignment of these words can vary 
between speakers but the pattern is widespread. Under our analysis nothing special need be said, as shown in (38).

(38) Initial words ending in syllabic sonorants: our analysis

\begin{tabular}{|c|c|c|c|c|}
\hline $\begin{array}{l}\text { LEXICAL } \\
\text { REPRESENTATION }\end{array}$ & $\begin{array}{l}\text { FIRST } \\
\text { ELEMENT }\end{array}$ & $\begin{array}{l}\text { SECOND } \\
\text { ELEMENT }\end{array}$ & $\begin{array}{l}\text { ACCENT } \\
\text { ASSIGNMENT }\end{array}$ & COMPOUND \\
\hline /fingr/ & 'finger ${ }_{1}$ & 'ring 1 & default A2 & 'finger,ring 2 \\
\hline /søppl/ & 'søppel ${ }_{1}$ & 'kasse ${ }_{2}$ & default A2 & 'søppel,kasse ${ }_{2}$ \\
\hline /hassl/ & 'hassel 1 & 'nøt & default A2 & 'hassel,nøt ${ }_{2}$ \\
\hline /ti: $\mathrm{gr}_{1} /$ & 'tiger 1 & 'sprang 1 & lex specified & 'tiger,sprang 1 \\
\hline /ka:bl ${ }_{1} /$ & 'kabel 1 & 'bane 2 & lex specified & 'kabel,bane ${ }_{1}$ \\
\hline
\end{tabular}

The first three words are underlyingly monosyllabic, e.g. /fingr/'finger, and thus not specified for accent 1 . Regular postlexical accent assignment would give them accent 1 . The last two compounds have lexically marked first members: 'tiger ${ }_{1}$, ' abel $_{1}$. Thus, under the compound accenting rule, any word which has 'finger as the first member would regularly get accent 2 ; however, any compound with 'tiger ${ }_{1}$ as the first member will have accent 1 .

Our analysis covers the simple compounds. Compounds with juncture or 'cohering suffixes' require further investigation although they also fit into our general story. $^{12}$

The final version of lexical accent specification and assignment in Norwegian is given in (39).

(39) Standard East Norwegian lexical accent specification (final version)

Lexical accent 1 [No morpheme or word bears accent 2 lexically]

Words: disyllabic:

monosyllabic:

names of places:

days of the week:

Prefixes: unstressed verbal

prefixes:

stressed verbal prefixes: 'fenrik ${ }_{1}$ 'ensign', 'aksje 1 'stock', pro'fessor 1 'professor', gene 'rator 1 'generator', etc.

ball $_{1}$ 'dance', sko 'shoe', 'sykkel 1 'bike', etc.

'Bergen 1, A'merika $_{1}$, etc.

'lordag 1 'Saturday', 'mandag ' Monday', etc.

be-1, for-1, ent-1

'an $1^{-},{ }^{\prime} a v_{1^{-}},{ }^{\prime}{ }^{\prime} m_{1-}$

Suffixes: -'ere $1,\left\{-" e r_{1}\right\}$ PLURAL, etc. 
a. Lexical accent 1 always dominates

b. Postlexical accent assignment (if not lexically specified)

$\{\ldots \sigma \sigma \ldots\}_{\omega} \rightarrow$ accent 2 ;

$\{\ldots \dot{\sigma}\}_{\omega} \rightarrow$ accent 1

Let us summarise Kristoffersen and Withgott \& Halvorsen's positions in comparison to ours. The crucial types of words that bring out the difference are monosyllabic hest vs. ball 'dance' and disyllabic 'tiger vs. 'finger. All singulars of these words have accent 1 when spoken in isolation. In the plural, ball adds no syllable since it is a neuter noun and remains monosyllabic and accent 1. Hest and 'finger have accent 2 plurals ('hester, 'fingrer) while 'tiger 1 remains accent 1 ('tigrer ${ }_{1}$ ). On the one hand, Kristoffersen and Withgott \& Halvorsen are forced to mark hest and 'finger with a floating $\mathrm{H}$ either as part of the stem or as part of the compound stem to obtain accent 2 compounds ('heste,kraft 2 , 'finger ring ${ }_{1}$ ). On the other hand, ball and 'tiger are their normal unspecified cases. We have exactly the opposite analysis. For us, ball $_{1}$ and 'tiger ${ }_{1}$ are lexically specified, which 'tiger ${ }_{1}$ maintains even when a syllable is added in the plural ('tigrer ${ }_{1}$ ). The monosyllabic stems in 'finger and hest are unspecified and both get postlexical accent 2 in the plural. Only words lexically specified for accent 1 induce accent 1 in compounds, everything else is accent 2 regardless of whether the initial word surfaces with accent 1 in the singular in isolation or not. Consequently, exceptional compound stem marking for Kristoffersen is reserved for a vast number of regular, inherited Germanic monosyllabic stems. Counting monosyllabic stems that trigger accent 1 and the ones that do not in Withgott \& Halvorsen's (1988) list, we find the following:

monosyllabic stems that trigger accent 1 in compounds: 130

monosyllabic stems that take default accent 2 in compounds: 269

For us, the special marking of accent 1 on monosyllabic nouns is reserved for a non-homogeneous set including those that take a special plural, or are borrowed.

A final point that needs to be addressed relates to the consequences of marking a handful of monosyllabic words with lexical accent 1 . We have claimed so far that stems bearing lexical accent 1 will always keep their accent, no matter what is added (see examples, prefix $\left\{b e_{-1}\right\}$ ). If this claim is correct then the monosyllabic lexically specified accent 1 words should bear accent 1 with all suffixes. Kristoffersen (p.c.) has pointed out that marking words like ball with lexical accent 1 has the same consequences as Withgott \& Halvorsen marking hest or land as accent 2 on the root since this accent never shows up anywhere other than in compounds. Actually, we feel this is not so. First of all, the set of words marked with accent 1 that do have a plural with accent 2 is very small. Words like land, on the other hand, which have accent 
2 compounds, are numerous. Indeed, Withgott \& Halvorsen's account is no different from Kristoffersen's since his special compound stem marking effects an enormous number of inherited, regular words. Surely it is better to mark 'exceptional' for a small set of really exceptional words. Kristoffersen's special marking on monosyllabic stems leads to 'exceptionally' marking 269 accent $2 \mathrm{~s}$ in compounds. We obtain this by our default, general compounding rule - no exceptional marking is necessary.

\section{REPRESENTATION OF ACCENTS}

Concerning the synchronic analysis of Swedish and Norwegian we have presented here, the burden is borne by accent 1 rather than accent 2 . This is essentially incompatible with all previous and recent phonological analyses, for both Swedish and Norwegian. In all other analyses it is accent 2 which is marked on morphemes, and it is accent 2 which is the 'active' member. Accent 2 has always been accepted as the dominant member in accounting for morphophonological alternations, primarily because of the phonetic manifestation as well as the phonological contour of accent 1 (regardless of dialect-specific differences), which is considered to be less complex. Why, then, do we claim that accent 1 is the distinctive accent? The principal reason for lexically specifying accent 1 was simply that (a) this is the accent involved in exceptions, and (b) dominance relations are directed by it. It seemed to us that in both Norwegian and Swedish all problematic cases, i.e. all oddities, involved accent 1. Once accent 1 is specified, the phonology works smoothly. In what follows, we summarise the assumptions of earlier work, in (41), and then proceed to sketch an outline of our view regarding accent specification and phonetic implementation.

(41) Assumptions about Scandinavian lexical accent

- ACCENT 2 IS MARKED, ACCENT 1 UNMARKED (Haugen \& Joos 1952; Rischel 1963/1983; Jasanoff 1966/1983; Haugen 1967/1983; Elert 1972; Bruce 1977; Withgott \& Halvorsen 1984; Riad 1998a, b, 2003a, b; Bruce \& Hermans 1999; Gussenhoven \& Bruce 1999; Kristoffersen 2000, and others).

- ACCENT IS PRIVATIVE Accent 2 is lexical, and accent 1 is the absence of lexical tone (Rischel 1963/1983, Jasanoff 1966/1983, Haugen 1967/1983, Elert 1972, Linell 1972, Lorentz 2001, Riad 2003a, and others); or accent 2 is listed in the lexicon, and accent 1 is introduced by rule (Withgott \& Halvorsen 1984).

- ACCENT IS EQUIPOLLENT Accent 1 and 2 are represented with the tonal string $\mathrm{H}+\mathrm{L}$. The difference lies in the alignment of the $\mathrm{H}$ or $\mathrm{L}$ tone. $\mathrm{H}^{*} \mathrm{~L}$ is the alignment for accent 2 and HL* for accent 1 (Haugen \& Joos 1952, Bruce 1977, Endresen 1977, Hoel 1981, Lorentz 1984, Gussenhoven \& Bruce 1999).

Contrary to all other approaches, in our analysis we do not represent lexically specified accent 1 as L or H. Rather, we adopt Gussenhoven's (1991) idea of accent 
marking for English, and we mark morphemes bearing lexical accent with an abstract diacritic $\left({ }^{\times}\right)$. Jasanoff $(1966 / 1983)$ also suggests using $(\times)$ to mark what he considers lexically specified accent, namely accent 2 . No phonetic correlate is represented with a diacritic. Thus, for example, the difference between the accent 2 infinitives 'tala in Central Swedish and 'tale 2 in Standard East Norwegian on the one hand and their accent 1 prefixed counterparts be 'tâl $a_{1}$ and be 'tâle $e_{1}$ on the other are indicated with a diacritic $\left({ }^{\mathrm{x}}\right)$. The diacritic indicates that the unstressed prefix $b{ }^{\mathrm{x}}$ - is lexically specified; the accent is ultimately associated with the stressed syllable of the word it attaches to. Thus, all words with the prefix $b^{\times} e^{-}$will inevitably have accent 1 . Reformulating the representations (9) and (31) in these terms gives us the following:

(42) Abstract lexical accent marking in Swedish and Norwegian

Central Swedish

Words with accent 1: $\quad$ têrmos 'thermos', tåxi 'taxi', mưskel 'muscle', etc.

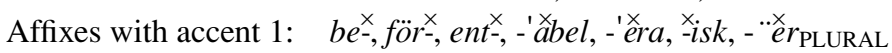

Standard East Norwegian

Words with accent 1: tềrmos 'thermos', mưskel 'muscle', bâll 'dance'

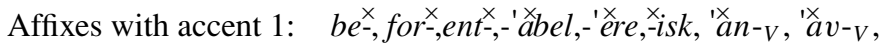

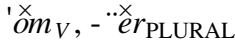

These lexically specified words will always be accent 1 , irrespective of any further affixation. Moreover, morphologically complex words formed with the affixes in (42) will always bear accent 1 . We now turn to the ultimate phonetic realisations of the accents.

\subsection{Phonetic realisation of accents across dialects}

Swedish and Norwegian dialects are well-known for their diversity in the phonetic realisation of the two contrasting accents (see Gårding (1978:30) for an overview). Lexical accent 1 is realised in some dialects with a low tone, in others with a high tone. Irrespective of whether accent 1 is realised as a $\mathrm{H}$ or $\mathrm{L}$ tone, the lexical marker is able to account for the surface realisations, since we do not specify lexical accent as being $\mathrm{H}$ or L. Marking lexical accent with a diacritic leaves room for dialectal differences. Therefore, in East Norwegian, for example, lexical accent $\left.{ }^{(}\right)$is realised with an L and default accent 2 with an $\mathrm{H}$. West Norwegian, on the other hand, realises lexical accent $\left({ }^{\mathrm{x}}\right)$ with an $\mathrm{H}$ and postlexical accent 2 with an $\mathrm{L}$, as shown in (43).

Opposite tonal specifications for accent 1 and 2

East Norwegian: Accent $1=\mathrm{L}$, Accent $2=\mathrm{H}$

West Norwegian: Accent $1=\mathrm{H}$, Accent $2=\mathrm{L}$ 
Perhaps the generalisation following Bruce's and Gårding's dialect surveys is the following: When tone is contrastive, then accent 1 and 2 have opposite tonal specifications. We follow Bruce, Lorentz, Riad, and others as to the tonal word template in (44).

\section{(44) Tonal word template}

Lexical accent $\left({ }^{\times}\right)+$Focus tone + Boundary tone

Each dialect specifies how the lexical accent diacritic is phonetically realised. Once that is known, the focus tone is predictable. The intonational boundary tone depends on the sentence type. Individual phonetic patterns in Swedish and Norwegian are given in (45).

\section{Phonetic manifestation in Central Swedish and Standard East Norwegian}

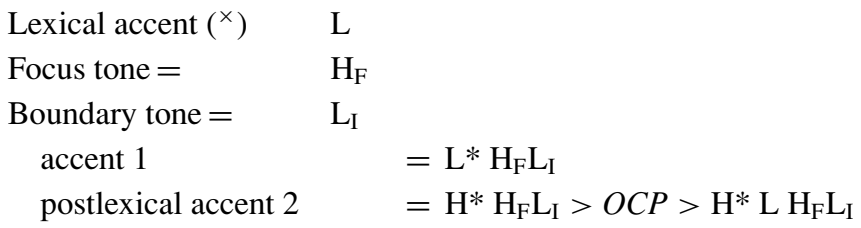

(cf. Lorentz 1984, Riad 1998a)

Thus, the bitonal contour of accent 2 is the consequence of a tonal insertion to break up identical tones.

\section{2 (Un)Predictability of lexical accent 1}

What does lexical specification mean in the context of complexity, markedness, and dominance? Without exception, researchers have assumed that accent 2 is MARKED since it has one high tone more than accent 1 . Consequently they have represented stems, affixes, and compound-stems with accent 2 that then dominates in affixed words and compounds. But is this really so? Is it not the case, rather, that accent 2 contours (phonetically varying across dialects) surface on Scandinavian polysyllabic words UNLESS something hinders them? And is this hindering element not invariably accent 1? One could compare such a blocking effect in stress rules in Germanic. Usually Germanic stress is never final, unless certain specific suffixes force it to be so. Scandinavian tone appears to have the same property. Accent 2 surfaces on all disyllabic trochees, UNLESS accent 1 blocks it, where blocking includes specific stressed and unstressed affixes as well as a set of idiosyncratic words, etc. Thus, in our view, accent 2 is not lexically specified since it is more general and predictable, while accent 1 is specified because it is more ad hoc, unpredictable, dominant and blocks default accent assignment. Had accent 2 been the lexical accent, we would expect more irregular distributions, but we do not find them. Instead, it is accent 1 words that are unpredictable. 
Riad (p.c.) draws attention to the fact that there is a tendency for words with the prosodic pattern of $\sigma \sigma \sigma$ to have accent 1 . If this were accepted as an overall prosodic constraint, it would account for infinitives with unstressed be-, etc. without having to specify it for lexical accent. This would have the same effect as Kristoffersen's morphological constraint (cf. (27) above). However, we face several problems. First, words of this pattern do have accent 2 as in $k o ' p i a_{2}$, ve'randa $a_{2}$, ana'konda $a_{2}$, etc. Second, the prosodic constraint does not solve instances like Norwegian 'anklage Verb $_{\text {, }}$ where the prefix is stressed but induces accent 1 . Third, there are many disyllabic words which surface with accent 1 and induce accent 1 in Norwegian and Southern Swedish compounds like åksje, which maintain accent 1 in the plural and we would have no prosodic explanation for these. Thus, although there may be such prosodic tendencies, the overwhelming evidence suggests that accent 1 needs lexical specification.

We maintain, like Rischel (1963/1983), Jasanoff (1966/1983), Haugen (1967/1983), Elert (1972) and Riad (2003a), that accent is privative in the sense that stems and affixes may or may not be specified for lexical accent. The actual phonetic manifestation is left up to the individual dialects as suggested above. We could compare this to Swedish and German, where high rounded vowels are specified for [HIGH] [LABIAL] in both languages but have different acoustic manifestations. In particular, the F2 values of Swedish [u:] [y:] are approximately $300 \mathrm{~Hz}$ lower than German [u:] [y:], whereas the F3 values are very similar (Fant 1973:96, Simpson 1998:216).

We can now return to idiosyncratic words that bear lexical accent 1 (tiger 'tiger', bâll 'dance'). Since our view is that all forms deviating from the norm bear accent 1 , it comes as no surprise that loans are assigned this accent since their prosodic as well as morphological make-up maybe uncertain and variable. Unlike Kock (1878), we do not think that the accent 1 assignment of loans mirrored the pitch marking of stressed syllables of the donor language, which in most cases would have been high pitch; rather, on the contrary, they were borrowed and marked with the lexical or special accent. And since speakers tend to be pertinacious in their behaviour, across Scandinavian dialects, accent 1 remains the lexically specified, novel, and distinctive tonal morpheme.

\section{ACKNOWLEDGEMENTS}

This research was made possible by funding from the Deutsche Forschungsgemeinschaft (German Research Foundation, SFB 471 and the Leibniz-Prize). We wish to thank Gösta Bruce, Elan Dresher, Larry Hyman, Frans Plank and Gjert Kristoffersen, and all the participants of the TIE workshops and our anonymous reviewers for their valuable comments. We are particularly grateful to Tomas Riad for 
his immensely helpful remarks and input. Earlier versions of this paper were presented at the TIE workshop, 20-24 March 2002 at Schloss Freudental, the INTAS workshop, February 2002 in Moscow, the 20th Scandinavian Conference on Linguistics, 7-9 January 2004 in Helsinki, and the TIE workshop 1-3 April 2004 in Cascais.

\section{NOTES}

1. This does not include the dialects with circumflex tone.

2. In Swedish we only encounter a few original r-stems that have such a contrast, fader 'father' sg. accent 2, fäder pl. accent 1, and even then there is an umlaut/non-umlaut vowel distinction.

3. Withgott \& Halvorsen also hypothesise an additional floating accent 2 . We turn to this later.

4. The one exception is 'bearbeta 2 'to cultivate'.

5. Riad (1998:86, fn. 29) points out that in Älvdalsmål words with be- bear accent 2 and suggests that this is an archaic feature. However, Jönsson-Steiner \& Lahiri (2004) show that poets like Nicander (1737) were sensitive to the fact that words with prefixes like $\{b e-\}$ do not bear accent as they ought, which means that these prefixes must have been special.

6. We discuss this in more detail in section 3.2.4.

7. The unstressed prefix $\{b e-\}$ is lexically specified for accent 1 . This means that after stress assignment, the stressed vowel will bear the tone associated with accent $1 \mathrm{~L}$ or $\mathrm{H}$, depending on the dialect. This will be discussed in more detail in section 5 .

8. It would make no difference whether we assume the stem for regel 'rule' to be disyllabic or monosyllabic. The crucial point is that the stem must be specified for accent 1 . In words like stu'dent, however, we do not have to consider this since the stressed syllable will never be a disyllabic trochee in the singular.

9. We could have also assumed a /-r/ as in Kristoffersen (2000). However, if we assumed /-r/, the syllabicity would be retained everywhere except after unstressed [e] and stressed V. Assuming that the suffix is a full vowel $+/ \mathrm{r} /$, i.e. /-er/, explains vowel deletion more effectively - two identical vowels do not surface (/'pike//er/ > *pikeer but /'opera//er/ > 'operaer).

10. Kristoffersen's 1992 analysis of $b e$-infinitives was different. The floating $\mathrm{H}$ of the infinitive suffix was linked to be-followed by an L which linked to 'the second next mora', which would be the stressed syllable of the verbal root. This results in accent 1 .

11. In his discussion of the Swedish dialect of Malmö, which has Norwegian-like accent, Riad suggests that stress clash (monosyllabic word + word) in a compound leads to accent 2. This is overridden by his two-morpheme generalisation.

12. We draw a distinction between linking $\{-e\}$ and linking $\{=s\}$, arguing in support of a clitic analysis of the latter. The general compounding story remains. 


\section{REFERENCES}

Bruce, Gösta. 1973. Tonal accent rules for compound stressed words in the Malmö dialect. Working papers 7, 1-35. Lund University, Phonetics Laboratory.

Bruce, Gösta. 1974. Tonaccentregler för sammansatta ord i några sydsvenska stadsmål. In Christer Platzack (ed.), Svenskans beskrivning 8, 62-75.

Bruce, Gösta. 1977. Swedish Word Accents in Sentence Perspective. Lund: Gleerup.

Bruce, Gösta \& Ben Hermans. 1999. Word tone in Germanic languages. In van der Hulst (ed.), 605-658.

d'Alquen, Richard \& Kevin Brown. 1992. The origin of Scandinavian accents I and II. In Irmengard Rauch, Gerald F. Carr \& Robert L. Kyes (eds.), On Germanic Linguistics: Issues and Methods. Berlin: Mouton de Gruyter, 61-79.

Elert, Claes-Christian. 1970. Ljud och ord $i$ svenskan. Uppsala: Almqvist \& Wiksell.

Elert, Claes-Christian. 1972. Tonality in Swedish: rules and a list of minimal pairs. In Evelyn Scherabon Firchow, Kaaren Grimstad, Nils Hasselmo \& Wayne A. O’Neil (eds.), Studies for Einar Haugen. The Hague: Mouton de Gruyter, 151-173.

Endresen, Rolf Theil. 1977. An alternative theory of stress and tonemes in Eastern Norwegian. NTS 31, 21-46. [Reprinted in 1983, in Jahr \& Lorentz (eds.), 362-387.]

Fant, Gunnar. 1973. Speech Sounds and Features. Cambridge, MA: MIT Press.

Gårding, Eva. 1978. The Scandinavian Word Accents (Travaux de L'institut de Linguistique de Lund 11). Malmö: Gleerup.

Gussenhoven, Carlos. 1991. The English rhythm rule as an accent deletion rule. Phonology 8, $1-35$.

Gussenhoven, Carlos \& Gösta Bruce. 1999. Word prosody and intonation. In van der Hulst (ed.), 233-271.

Haugen, Einar. 1967/1983. On the rules of Norwegian tonality. Language 43, 185-202.

[Reprinted in 1983, in Jahr \& Lorentz (eds.), 293-309.]

Haugen, Einar \& Martin Joos. 1952. Tone and intonation in East Norwegian. Acta Philologica Scandianavica 22, 41-64. [Reprinted in 1983, in Jahr \& Lorentz (eds.), 179-201.]

Hoel, Thomas. 1981. An intonation analysis of the Oslo dialect. In Thorstein Fretheim (ed.), Nordic Prosody II. Trondheim: Tapir, 96-110.

Hulst, Harry van der (ed.). 1999. Word Prosodic Systems in the Languages of Europe. Berlin: Mouton.

Jahr, Ernst Håkan \& Ove Lorentz (eds.). 1983. Prosodi/Prosody. Oslo: Novus.

Jasanoff, Jay H. 1966/1983. Remarks on the Scandinavian word tones. Lingua 16, 71-81. [Reprinted in 1983, in Jahr \& Lorentz (eds.), 282-292.]

Jönsson-Steiner, Elisabet \& Aditi Lahiri. 2004. Eighteenth century prefixed loans in Swedish. Poster given at the TIE Conference in Santorini, 9-11 September 2004.

Kock, Axel. 1878. Språkhistoriska undersoekningar om svensk accent. Lund: C. W. K. Gleerups.

Kristoffersen, Gjert. 1992. Tonelag i sammensatte ord i østnorsk. Norsk lingvistisk tidsskrift 10, 39-65.

Kristoffersen, Gjert. 1993. An autosegmental analysis of East Norwegian pitch accent. In Björn Granström \& Lennart Nord (eds.), Nordic Prosody 6. Stockholm: Almqvist \& Wiksell International, 109-122.

Kristoffersen, Gjert. 2000. The Phonology of Norwegian. Oxford: Oxford University Press. Lahiri, Aditi, Tomas Riad \& Haike Jacobs. 1999. Diachronic prosody. In van der Hulst (ed.), $335-422$. 
Linell, Per. 1972. Remarks on Swedish morphology. Report No. RUUL 1. Department of Linguistics, Uppsala University.

Lorentz, Ove. 1984. Stress and tone in an accent language. In Claes-Christian Elert et al. (eds.), Nordic Prosody III. Umeå \& Stockholm: Almquist and Wiksell, 165-178.

Lorentz, Ove. 2001. Tone doubling and Scandinavian Tonogenesis. Paper presented at the Stanford Phonology Workshop, March 8, 2001.

Nicander, Anders. 1737. Oförgripelige anmerckningar öfwer swenska skaldekonsten. Stockholm: Johan Laur. Horrn, Kong. Ant. Achiv.

Perridon, Harry. 2003. On the origin of the Scandinavian word accents. Talk presented at the First International Conference on Franconian Tone, University of Leiden, 13-14 June 2003.

Riad, Tomas. 1998a. The origin of Scandinavian tone accents. Diachronica 15, 63-98.

Riad, Tomas. 1998b. Towards a Scandinavian accent typology. In Wolfgang Kehrein \& Richard Wiese (eds.), Phonology and Morphology of the Germanic Languages (Linguistische Arbeiten 386). Tübingen: Niemeyer, 77-109.

Riad, Tomas. 2003a. Diachrony of the Scandinavian accent typology. In Paula Fikkert \& Heike Jacobs (eds.), Development in Prosodic Systems (Studies in Generative Grammar 58). Berlin \& New York: Mouton de Gruyter, 91-144.

Riad, Tomas. 2003b. Distribution of tonal accent in Scandinavian morphology. Paper presented at the First International Workshop on Franconian Tone Accents Leiden, 13-14 June 2003.

Riad, Tomas. 2003c. Bestämdhetssuffixens form och tvåstavigheten. In Lars-Olof Delsing, Cecillia Falk, Gunlög Josefsson, Halldór A. Sigurdsson (eds.), Grammar in Focus (Festskrift till Christer Platzack den 18 november 2003). Lund: Wallin \& Dalholm, $145-152$.

Rischel, Jørgen. 1963/1983. Morphemic tone and word tone in Eastern Norwegian. Phonetica 10, 154-164. [Reprinted in 1983, in Jahr \& Lorentz (eds.), 266-277.]

Simpson, Adrian P. 1998. Phonetische Datenbanken des Deutschen in der empirischen Sprachforschung und der phonologischen Theoriebildung. In Klaus J. Kohler (ed.), Arbeitsberichte des Instituts für Phonetik und digitale Sprachverarbeitung Universität Kiel 33, Kiel: IPDS Kiel.

Withgott, Meg \& Per-Kristian Halvorsen. 1984. Morphological Constraints on Scandinavian Tone Accent. Center for the Study of Language and Information, Stanford University. Report. No. CSLI-84-11.

Withgott, Meg \& Per-Kristian Halvorsen. 1988. Phonetic and phonological considerations bearing on the representation of East Norwegian accent. In Harry van der Hulst \& Norval Smith (eds.), Autosegmental Studies on Pitch Accent. Dordrecht: Foris, 279-294. 